NBER WORKING PAPER SERIES

\title{
SHIFT-SHARE INSTRUMENTS AND THE IMPACT OF IMMIGRATION
}

\author{
David A. Jaeger \\ Joakim Ruist \\ Jan Stuhler \\ Working Paper 24285 \\ http://www.nber.org/papers/w24285 \\ NATIONAL BUREAU OF ECONOMIC RESEARCH \\ 1050 Massachusetts Avenue \\ Cambridge, MA 02138 \\ February 2018
}

Jan Stuhler acknowledges funding from the Spanish Ministry of Economy and Competitiveness (MDM2014-0431 and ECO2014-55858-P), the Fundación Ramón Areces, and the Comunidad de Madrid (MadEco-CM S2015/HUM-3444). We thank Josh Angrist, Michael Amior, Andreas Beerli, George Borjas, Christian Dustmann, Anthony Edo, Jesús Fernández-Huertas Moraga, Tim Hatton, Jennifer Hunt, Larry Katz, Joan Llull, Marco Manacorda, Simen Markussen, Joan Monras, Elie Murard, Barbara Petrongolo, Uta Schõnberg, JC Suarez Serrato, Uwe Sunde, Joachim Winter and seminar and conference participants at the Banco de España, CERGE-EI, Collegio Carlo Alberto, CREST, Duke University, the Frisch Centre in Oslo, Gothenburg University, Helsinki Center of Economic Research, IZA, London School of Economics, Lund University, Luxembourg Institute of Socio-Economic Research, Milan Labor Lunch Series, Norwegian School of Economics, Queen Mary University, Royal Holloway University, Universidad Autonoma de Barcelona, Uppsala University, University of Navarra, the 2017 PSECEPII Workshop on Migration, and the 2017 NBER Labor Studies Fall meeting for comments. The views expressed herein are those of the authors and do not necessarily reflect the views of the National Bureau of Economic Research.

NBER working papers are circulated for discussion and comment purposes. They have not been peer-reviewed or been subject to the review by the NBER Board of Directors that accompanies official NBER publications.

(C) 2018 by David A. Jaeger, Joakim Ruist, and Jan Stuhler. All rights reserved. Short sections of text, not to exceed two paragraphs, may be quoted without explicit permission provided that full credit, including $\odot$ notice, is given to the source. 
Shift-Share Instruments and the Impact of Immigration

David A. Jaeger, Joakim Ruist, and Jan Stuhler

NBER Working Paper No. 24285

February 2018

JEL No. C36,J15,J21,J61

\begin{abstract}
A large literature exploits geographic variation in the concentration of immigrants to identify their impact on a variety of outcomes. To address the endogeneity of immigrants' location choices, the most commonly-used instrument interacts national inflows by country of origin with immigrants' past geographic distribution. We present evidence that estimates based on this "shiftshare" instrument conflate the short- and long-run responses to immigration shocks. If the spatial distribution of immigrant inflows is stable over time, the instrument is likely to be correlated with ongoing responses to previous supply shocks. Estimates based on the conventional shift-share instrument are therefore unlikely to identify the short-run causal effect. We propose a "multiple instrumentation" procedure that isolates the spatial variation arising from changes in the countryof-origin composition at the national level and permits us to estimate separately the short- and long-run effects. Our results are a cautionary tale for a large body of empirical work, not just on immigration, that rely on shift-share instruments for causal inference.

David A. Jaeger

CUNY Graduate Center

365 Fifth Ave.

New York, NY 10016

and University of Cologne

and NBER

djaeger@gc.cuny.edu

Joakim Ruist

Department of Economics

University of Gothenburg Box

640

40530 Göteborg

Sweden

joakim.ruist@economics.gu.se

Jan Stuhler

Department of Economics

Universidad Carlos III de Madrid

Calle Madrid 126

28903 Getafe

Spain

jstuhler@eco.uc3m.es
\end{abstract}


Studies of the impact of immigration often rely on spatial variation in immigrant inflows for identification. In the hopes of addressing the endogeneity of the location choices of new immigrants, inflows at an aggregate level are typically combined with the lagged geographic distribution of immigrants to create an instrument (Altonji and Card 1991, Card 2001). With dozens of publications in leading journals, the "past settlement" instrument has been used to identify supposedly exogenous labor supply shocks in the spatial correlation literature on immigration as well as in other contexts. It is also a prominent example of "shift-share" instruments with the same underlying rationale - combining local economic compositions with shifts on the aggregate level to predict variation in a variable of interest. In a quest for better identification, shift-share instruments have become popular in a wide range of literatures, introducing spatial or other forms of cross-sectional variation also to literatures that traditionally relied on time-series analysis. ${ }^{1}$

Despite a proliferation of studies, the past settlement instrument has not resolved a long-standing dispute regarding the labor market effects of immigration or, more generally, how local labor markets adjust to supply shocks (see, for example, Borjas 2014, Card and Peri 2016). Estimates of immigrants' impact on wages that rely only on the past settlement instrument tend to be less negative than those from the factor proportions approach, or those that rely on natural quasi-experiments (see, for example, Aydemir and Kirdar 2014, Dustmann, Schönberg, and Stuhler 2017, Monras 2015, and Llull 2018). Estimates from the spatial correlation approach also appear to be more variable (Dustmann, Schönberg, and Stuhler 2016), changing sign even when applied to different time periods within the same country (Borjas 1999).

\footnotetext{
${ }^{1}$ The classic reference is Bartik (1991), who combines the local industry composition with national changes in employment across industries to isolate local labor demand shocks. Kovak (2013) interacts the local industry composition with tariff changes to examine the impact of trade reform. Autor, Dorn, and Hanson (2013) interact local industry shares with aggregate trade flows to examine the impact of Chinese imports on labor markets in the US. Shift-share instruments have also been used to isolate exogenous variation in local public spending (e.g. Nakamura and Steinsson 2012, Wilson 2012), foreign aid (Nunn and Qian 2014), credit supply (Greenstone, Mas, and Nguyen 2015), portfolio allocation (Calvet, Campbell, and Sodini 2009), market size (Acemoglu and Linn 2004), judge leniency (Kling 2006), import prices on the firm level (de Roux et al. 2017, Piveteau and Smagghue 2017), automatization of routine tasks (Autor and Dorn 2013), and robotization (Acemoglu and Restrepo 2017, Graetz and Michaels 2017). See Goldsmith-Pinkham, Sorkin, and Swift (2017) for additional examples.
} 
We show that these inconsistencies arise partly from the conflation of the short- and long-run responses to immigrant arrivals. The problem stems from the interplay of two factors. First, local shocks may trigger general equilibrium adjustments that gradually offset their local impact, with a period of positive wage growth following the potentially negative effect of a local supply shock. Second, the country of origin composition and settlement patterns of immigrants are often correlated over time, with the same cities repeatedly receiving large inflows. These two factors together suggest that the spatial correlation approach may conflate the (presumably negative) short-run wage impact of recent immigrant inflows with the (presumably positive) movement towards equilibrium in response to previous immigrant supply shocks.

A concern in the existing literature is that general equilibrium adjustments occur too quickly, offsetting the (local) impact of immigrant arrivals before the measurement of wages and biasing spatial correlation estimates towards zero (Borjas, 1999, Borjas 2006). Our argument suggests that adjustments are problematic regardless of their speed, however, causing the past settlement instrument to violate the necessary exogeneity assumption. The resulting bias can dominate the short-term impact of current immigration, resulting in a sign reversal and a positive estimated effect of immigration on wages. The causes for violations of exogeneity of the instrument become clearer when placing the past settlement instrument in a theoretical framework rather than in the "ad hoc" implementations that are common in the literature.

We illustrate how use of the past settlement instrument exacerbates potential biases using data from the U.S. Census and American Community Survey from 1960 to 2011. Because the country of origin mix of the inflow of immigrants to the U.S. is so similar over time, the correlation across metropolitan areas between the instrument and its lag is consistently high (between 0.96 and 0.99 since the 1980s) and even exceeds the corresponding correlation in actual inflows. As a consequence, the conventional instrumental variable approach captures not only the short-term impact, but also the longer-term adjustment process to previous inflows. The resulting estimates have no clear interpretation, because the respective weights on the short and long term vary across time and across applications. The instrument's 
impressive ability to predict current flows, its greatest strength, is also potentially a major weakness. If the instrument is "too strong" it is highly unlikely to meet the exclusion restriction for a valid instrument and actually separate the endogenous component of the immigrant inflows from the exogenous component. The flipside of this argument is that the prospects to satisfy the exclusion restriction may be better in settings in which the first-stage link is weaker because immigrant inflows have been less stable over time, as is the case in many European countries.

Our results suggest that periods with substantial changes in the country of origin composition may provide variation that can be exploited with a variant of the shift-share strategy. By instrumenting both current and past immigrant inflows with versions of the past settlement instrument that vary only in their national components, we are able to isolate the variation in inflows that is uncorrelated with current local demand shocks as well as the process of adjustment to past supply shocks. This "multiple instrumentation" procedure places substantial demands on the data relative to the single instrument case, as the consequences of current and past immigrant arrivals can be distinguished only if there is sufficient innovation in their composition at the national level. We show that only in the 1970s is there sufficient innovation in the country-of-origin composition to use our procedure. The inflows after 1980, in contrast, are not conducive to such analyses because there is little variation in the countries that source immigrants to the U.S.

We estimate that the initial impact of immigration on natives' wages in the 1970s is more negative than estimates based on the conventional shift-share instrument would suggest. The estimated impact of the (lagged) immigrant inflow in the 1960s on wage growth in the 1970s is positive, however, and in some specifications of similar magnitude as the negative impact of the 1970s inflow. Our results suggest that areas with large immigrant flows experience a temporary, but not persistent negative impact on local wages. The short-term response is consistent with a standard factor proportions model, in which an increase in the supply of one factor leads to a reduction of its price. The longer-term adjustment indicates strong but gradual general equilibrium responses. 
A slow dynamic adjustment process poses a particular problem for the past settlement instrument in the immigration literature, but in principle the issue is relevant for other types of shift-share instruments that combine local "shares" and aggregate "shifts" to generate spatial variation. Local shares are often highly serially correlated, whether constructed from the composition of demographic groups, industries or other characteristics. Validity of the shift-share instrument requires that one of two conditions holds: either the national shifts are not serially correlated, or the variable of interest does not trigger dynamic adjustments in outcomes. In contexts where there are sudden shocks at the national level, shift-share instruments may meet the first condition. In other cases, variants of the shift-share methodology, such as the one proposed here, should be used to isolate variation that is uncorrelated with past shocks and to permit a causal interpretation of the results.

\section{Spatial Correlations and the Past Settlement Instrument}

By number of publications, the spatial correlation approach is the dominant identification strategy in the immigration literature. ${ }^{2}$ Its central identification issue is the selection problem: immigrants do not randomly sort into locations, but rather are attracted to areas with favorable demand conditions (Jaeger 2007). A simple comparison between high- and low-immigration areas may therefore yield a biased estimate of the impact of immigration. The problem is notoriously difficult to solve and arises even in those cases in which natural quasi-experiments generate exogenous variation in immigrant inflows at the national level.

To address the selection problem, most studies exploit the observation that immigrants tend to settle into existing cities with large immigrant populations. This tendency, noted in Bartel (1989) and Lalonde and Topel (1991), was first exploited by Altonji and Card (1991) to try to identify the causal

\footnotetext{
${ }^{2}$ See Peri (2016), Dustmann, Schönberg and Stuhler (2016), or the National Academy of Science (2016), for recent reviews. The main alternative is to exploit differences in the concentration of immigrants across skill (e.g. educationexperience) groups (Borjas 2003). The skill-cell approach identifies only relative effects and can be sensitive to the definition of skill groups and other assumptions (see Dustmann and Preston 2012, Borjas 2014, and Dustmann, Schönberg, and Stuhler 2016).
} 
impact of immigration on natives' labor market outcomes. Altonji and Card use only the geographic distribution of all immigrants, however, and Card (2001) refined this instrument by exploiting Bartel's observation that immigrants locate near previous immigrants from the same country of origin. For each labor market, he created a predicted inflow based on the previous share of the immigrant population from each country of origin combined with the current inflow of immigrants from those countries of origin at the national level.

Following Card (2009), the shift-share instrument can be defined as

$$
\tilde{m}_{j t}=\sum_{o} \frac{M_{o j t^{0}}}{M_{o t^{0}}} \frac{\Delta M_{o t}}{L_{j t-1}}
$$

where $M_{o j t^{0}} / M_{o t^{0}}$ is the share of immigrants from country of origin $o$ in location $j$ at reference date $t^{0}$ that predates $t, \Delta M_{o t}$ is the number of new arrivals from that country at time $t$ at the national level, and $L_{j t-1}$ is the local population in the previous period. The expected inflow rate $\widetilde{m}_{j t}$ is therefore a weighted average of the national inflow rates from each country of origin (the "shift"), with weights that depend on the distribution of earlier immigrants at time $t^{0}$ (the "shares"). The potential advantage of this specification arises from the considerable variation in the geographic clustering of immigrants from different countries of origin, i.e. there is a large amount of variation across areas and origin groups in $M_{o j t^{0}} / M_{o t^{0}}$. We refer to $\widetilde{m}_{j t}$ as the "past settlement instrument", but other terms are used in the literature (e.g. "network," "supply-push," or "enclave instrument"). Like all shift-share instruments, the past settlement instrument has intuitive appeal because it generates variation at the local level by exploiting variation in national inflows, which are arguably less endogenous with regard to local conditions. ${ }^{3}$

It is difficult to overstate the importance of this instrument for research on the impact of immigration. Few literatures rely so heavily on a single instrument or variants thereof. Appendix Table A.1 presents a list of articles published in top general and field journals in economics, plus a number of

\footnotetext{
${ }^{3}$ Studies vary in their choice of $t^{0}$ and how temporally distant it is from $t$. Saiz (2007) predicts national immigrant inflows using characteristics from each origin country to address the potential endogeneity of national inflows to local conditions. Wozniak and Murray (2012) and Hunt (2017) remove the area's own inflows from the national inflow rate to reduce the endogeneity to local conditions.
} 
recent papers that perhaps better reflect current usage of the instrument. ${ }^{4}$ With around 60 publications in the last decade alone (and many more not listed here), it is one of the most popular instrumental variables in labor economics. While most applications focus on questions related to immigration, authors have begun to use the instrument as a convenient way to generate (potentially exogenous) variation in local conditions to examine outcomes like fertility (Furtado and Hock 2010) or parental time investment (Amuedo-Dorantes and Sevilla 2014).

The arguments offered in support of the validity of the instrument vary somewhat across studies. A typical motivation is given by Card (2009):

"If the national inflow rates from each source country are exogenous to conditions in a specific city, then the predicted inflow based on [Card's] equation (6) will be exogenous."

Although this statement captures the instrument's intuitive appeal, the term "exogenous" can be misunderstood. ${ }^{5}$ The instrument is a function of national inflow rates and local immigrant shares and may therefore not be exogenous in the sense of satisfying the exclusion restriction required for a valid instrument if the shares are correlated with unobserved local conditions, even if the national inflow rates are unrelated to those conditions (as shown formally in Goldsmith-Pinkham, Sorkin, and Swift 2017).

To the best of our knowledge, ours is the first attempt to evaluate the validity of the instrument within a simple model of labor market adjustment, although various concerns have been expressed previously. ${ }^{6}$ Borjas (1999) notes that the exclusion restriction may be violated if local demand shocks are serially correlated, leading to correlation between the immigrant shares used in the construction of the instrument and subsequent demand shocks. Pischke and Velling (1997) note that mean revision in local

\footnotetext{
${ }^{4}$ Most studies listed in Appendix Table A.1 use a version of the Card (2001) instrument as their main strategy to address the selection bias, although some use the simpler Altonji and Card (1991) variant. Others combine the past settlement instrument with other (mostly distance-based instruments) to increase strength of the first-stage or use the instrument for robustness tests or as a reference point for other identification strategies.

${ }^{5}$ Deaton (2010) argues that a lack of distinction between "externality" (i.e. the instrument is not caused by variables in the outcome equation) and "exogeneity" (validity of the IV exclusion restriction) causes confusion in applied literatures. This distinction is particularly useful with regard to shift-share instruments, which appeal to the notion of externality.

${ }^{6}$ Goldsmith-Pinkham, Sorkin and Swift (2017) discuss the identifying assumptions underlying the shift-share strategy in a static setting in work that is complementary to ours. Our focus is on the complications that arise from repeated shocks and the dynamic adjustment of labor markets.
} 
unemployment rates may introduce bias if immigrant shares are correlated with the unemployment rate, and Amior (2017) notes that immigrant shares tend to be correlated with area-specific demand shocks related to the local industry structure.

None of these concerns appear problematic enough, however, to explain the surprisingly varying and sometimes positive estimates produced by using the past settlement instrument to identify the impact of immigration on local wages. In particular, serial correlation in local labor demand should be addressed if the instrument is constructed using settlement patterns that are sufficiently lagged (e.g. Dustmann, Fabbri, and Preston 2005, Wozniak and Murray 2012, Dustmann, Frattini, and Preston 2013, and Orrenius and Zavodny 2015). We argue instead that estimates using the past settlement instrument conflate the short and long-run effects of immigration. The instrument almost surely violates the exogeneity assumption by being correlated with the dynamic response to local shocks. As we show, the common strategy of choosing $t^{0}$ to be at a substantially earlier point in time offers no protection because the violation arises not from correlates of the initial immigrant distribution, but from the endogenous response to immigrant inflows themselves.

\section{The Past Settlement Instrument and Local Labor Market Adjustments}

We examine the validity of the past settlement instrument in a model of local labor markets. The core issue can be described in a simple dynamic setting, in which local labor markets adjust in response to spatial differentials in current economic conditions. We examine concerns raised in the previous literature, and proposed solutions, and then turn towards problems that stem from the prolonged adjustment in response to local shocks.

Consider the choice of an immigrant entering the country. A simplified version of the immigrant location choice model (e.g. Bartel 1989, Jaeger 2007) suggests that immigrants choose a location $j$ to maximize their utility 


$$
U_{o j t}=U\left(\frac{M_{o j t-1}}{M_{o t-1}}, \frac{w_{j t}}{\overline{w_{t}}}\right)
$$

where $w_{j t} / \overline{w_{t}}$ is the relative wage premium offered by labor market $j$ at time $t, \bar{w}_{t}=(1 / J) \sum_{j} w_{j t}$ is the unweighted average wage across areas, and $M_{o j t-1} / M_{o t-1}$ is the share of the stock of immigrants from country of origin $o$ living in location $j$ just prior to the immigrants' arrival. Given the results of Jaeger (2007), we assume both first partial derivatives of $U$ are positive, so that immigrants are attracted to labor markets with relatively higher wages and to locations with higher shares of previous immigrants from their country of origin, which motivates the instrument.

The local labor aggregate consists of natives, $N_{j t}$, and immigrants, $M_{j t}$, with $L_{j t}=N_{j t}+M_{j t}$ if immigrants and natives are perfect substitutes. Holding $N_{j t}$ fixed over time and abstracting from outmigration, internal migration, or death of previous immigrants such that $M_{j t}=\Delta M_{j t}+M_{j t-1}$, where $\Delta M_{j t}$ is the flow of new migrants to location $j$ between $t$-1 and $t$, the impact of new immigrants on labor supply is

$$
m_{j t} \equiv \log \left(\Delta M_{j t}+L_{j t-1}\right)-\log \left(L_{j t-1}\right) \approx \frac{\Delta M_{j t}}{L_{j t-1}}
$$

If labor markets are not in spatial equilibrium, immigrant arrivals in labor market $j$ will be partly determined by the distribution of previous immigrants and partly by current local demand conditions. We can express the immigration rate in location $j$ as function of the attraction of previous settlements of immigrants from the same country of origin and of labor market conditions as

$$
m_{j t} \approx(1-\lambda) \underbrace{\sum_{o} \frac{M_{o j t-1}}{M_{o t-1}} \frac{\Delta M_{o t}}{L_{j t-1}}}_{\begin{array}{c}
\text { past settlements } \\
\text { pull }
\end{array}}+\lambda \underbrace{\frac{w_{j t}}{\overline{w_{t}}} \frac{1}{J} \frac{\Delta M_{t}}{L_{t-1}}}_{\begin{array}{c}
\text { labor market } \\
\text { pull }
\end{array}},
$$

where $\lambda$ measures the relative importance of labor market conditions in determining immigrant locations and we assume $0<\lambda<1$ because both arguments in (1) positively affect utility. Without loss of generality, we have assumed both the past settlement pull and the labor market pull are linearly related to immigrant inflows and that the arguments in equation (2) are separable. The traditional shift-share 
instrument differs from the first term only by choice of the base period and is clearly correlated with immigrant inflows. If $t^{0}=t-1$, the past settlements pull and the instrument are identical.

To place immigrant inflows in the context of labor demand, we assume that output in labor market $j$ at time $t$ is given by the production function

$$
Y_{j t}=\theta_{j t} K_{j t}^{\alpha} L_{j t}^{1-\alpha}
$$

where $L_{j t}$ is labor, $K_{j t}$ capital, $\theta_{j t}$ is local total factor productivity and $\alpha$ is capital's share of output. Labor is paid its marginal product such that

$$
\log w_{j t}=\log (1-\alpha)+\log \theta_{j t}+\alpha \log k_{j t}
$$

with $k_{j t}=K_{j t} / L_{j t}$ denoting the capital-labor ratio. If in the long run capital is perfectly elastically supplied at price $r$, the optimal capital-labor ratio will be

$$
\log k_{j t}^{*}=\frac{1}{1-\alpha} \log \left(\frac{\alpha}{r}\right)+\frac{1}{1-\alpha} \log \theta_{j t} .
$$

It will be affected by the local productivity level $\theta_{j t}$ but, because of the constant returns to scale assumption inherent in the production technology, not by the local labor aggregate $L_{j t}$. In the short run, however, the local capital-labor ratio will not adjust completely and will deviate from its optimum.

\section{Local Adjustments to Supply Shocks}

A key issue for the spatial correlation approach is the local adjustment process - in particular the responses of other factors of production - triggered by immigrant-induced local labor supply shocks. ${ }^{7}$ If other factors adjust quickly, the observed impact of immigration at the local may not represent the impact at the national level. In particular, the longer the time elapsed between the supply shock and measurement, the less likely the data will uncover any impact of immigrants on local wages (Borjas 1999). Researchers

7 Labor supply shocks may affect capital flows (Borjas 1999) and internal migration (Card 2001, Amior and Manning 2017), but may also affect human capital accumulation (Smith 2012, Hunt 2017), the production technology of firms (Lewis 2011, Dustmann and Glitz 2015), or occupational choice (Peri and Sparber 2009). In principle, the gradual adjustment of any of these factors potentially affects the validity of the shift-share instrument. 
therefore assume that estimates exploiting the spatial distribution of immigrants are biased towards zero (e.g. Borjas 2006, Cortés 2008), or argue that only limited spatial adjustments occur in their period of study.

Research on regional evolutions in the U.S. concludes, however, that spatial adjustments can take around a decade or more (e.g. Blanchard and Katz 1992, Ebert and Stone, 1992, Greenaway-McGrevy and Hood, 2016). There is little work on the dynamic response to immigration, but the available evidence also points to prolonged adjustment periods. Cohen-Goldner and Paserman (2011) find that high-skilled immigration to Israel lowers native wages in the short run, but that the effect dies out after 5-7 years. Monras (2015) finds a more rapid response in the U.S. in response to Mexican migration after the 1995 peso crisis, while Braun and Weber (2016), examining post-World War II in-migration to Germany, and Edo (2017), examining wage dynamics during repatriation in France following Algerian independence, document more prolonged adjustment periods lasting a decade or more. Local labor markets appear not to fully adjust even long after other types of shocks (e.g. increased trade with China, see Autor, Dorn, Hanson 2016).

Although the relative importance of the underlying adjustment channels is disputed (e.g. Card 2001, Borjas 2014), our argument is not specific to any particular mechanism. To illustrate our point, we therefore consider an error correction model that allows for wages to respond to contemporaneous supply shocks, and for labor market dynamics in form of the lagged disequilibrium term. ${ }^{8}$ For simplicity we focus on capital adjustments and assume that the local capital-labor ratio does not equilibrate immediately in period $t$, but rather adjusts sluggishly in response to labor supply shocks according to

$$
\log k_{j t}=\log k_{j t-1}-m_{j t}+\gamma\left(\log k_{j t-1}^{*}-\log k_{j t-1}\right)
$$

The capital-labor ratio declines in response to immigrant inflows but, barring any subsequent shock, will only return to its optimal level over time. The coefficient $\gamma$ measures the share of necessary adjustments to return to the optimal capital-labor ratio that takes place in the subsequent period. Intuitively, $\gamma$ measures

\footnotetext{
${ }^{8}$ Amior and Manning (2017) consider a similar error correction model with regard to population dynamics in the response to labor demand shocks.
} 
the amount of the adjustment process to shocks in period $t-1$ that occurs in period $t$, with larger values of $\gamma$ indicating that the labor market rebounds more completely. As we use decadal data the assumption that labor markets recover nearly completely in the subsequent decade, i.e. $\gamma \approx 1$, might not be implausible, but our argument also holds if the adjustment process is slow $(0<\gamma \ll 1)$, begins immediately in period $t$, is triggered by the anticipation of immigrant inflows, or if the recovery is only partial.

\section{Selection and Dynamic Adjustment Biases}

Consider now the impact of immigration on wage changes. Substituting equation (8) into a firstdifferenced version of equation (6) and adding constant and disturbance terms gives

$$
\Delta \log w_{j t}=\beta_{0}+\beta_{1} m_{j t}+\left[\Delta \log \theta_{j t}-\beta_{1} \gamma\left(\log k_{j t-1}^{*}-\log k_{j t-1}\right)+\epsilon_{j t}\right]
$$

where $\beta_{1}$, the short-term impact of immigration-induced labor supply changes, is the object of interest (in our model $\beta_{1}=-\alpha$ ), and $\beta_{0}$ represents the secular growth in wages. The quantity in square brackets is unobserved to the econometrician. We will assume that $\epsilon_{j t}$ is orthogonal to $m_{j t}$ for all $j$ and $t$.

The first term in brackets illustrates the endogeneity problem that the instrument is designed to address. Because wages are affected by local demand shocks (equation 6) and immigrant flows are affected by local wage premia (equation 4$), m_{j t}$ will be correlated with $\Delta \log \theta_{j t}$. Because this correlation is thought to be positive, OLS estimates of $\beta_{1}$ are presumed to be upward biased estimates of the true shortterm impact. The literature largely focuses on how the past settlement instrument, $\widetilde{m}_{j t}$, addresses this selection problem. ${ }^{9}$ The instrument will address the selection problem if demand shocks are unrelated to the initial distribution of immigrants used to construct the instrument. Productivity or other labor demand

\footnotetext{
${ }^{9}$ Most of the literature uses first-differenced or fixed-effect specifications (e.g. Dustmann, Fabbri, and Preston 2005). The instrument is unlikely to address selection in wage levels. OLS estimates are biased by non-random sorting of recent arrivals with respect to wage levels, but IV estimates would suffer from non-random sorting of immigrant stocks. There is little reason to expect that the latter is much less of a concern since the past settlement instrument suggests a close relationship between stocks and new arrivals, and spatial differences in wage levels are persistent (Moretti 2011).
} 
shocks can be serially correlated (Amior and Manning 2017), however, leading to a correlation with the initial distribution of immigrants. The literature has noted this potential problem (Borjas 1999, Hunt and Gauthier-Loiselle 2010, Aydemir and Borjas 2011, Dustmann, Frattini, and Preston 2013, Dustmann and Glitz 2015, among others) and has addressed it by testing for serial correlation in the residuals of the wage regression (e.g. Dustmann, Frattini and Preston 2013) or by lagging the base period $t^{0}$ used to construct the instrument to minimize its correlation with current demand shifts (e.g. Hunt and Gauthier-Loiselle 2010). Since our concern is not about time dependence in external processes, we abstract from this issue by assuming that $\log \theta_{j t}$ follows a random walk. If, in addition, the flow of immigrants at the national level is unaffected by local demand conditions (as we assume here and as is plausible in our empirical setting) the instrument will be uncorrelated with $\Delta \log \theta_{j t}$.

\section{The IV Estimator with Repeated Inflows and Dynamic Adjustment}

Even in the absence of serial correlation in $\Delta \log \theta_{j t}$, labor market adjustment can generate endogeneity issues that invalidate the past settlement instrument. The literature has essentially ignored the second component of the disturbance term in equation (9), the dynamic adjustment process, which creates an endogeneity problem for the shift-share instrument. Local labor market shocks trigger general equilibrium adjustments that gradually offset the initial negative wage effect and lead to subsequent recovery and positive wage growth. If these adjustments are slow enough, they may still be ongoing during the subsequent observational period, even at a decadal frequency. If the country of origin distribution of immigrant inflows is highly serially correlated, there is a high degree of correlation over time in the locations of new immigrants. The past settlement instrument aggravates this issue, as it is predicated on the existence of some degree of serial correlation in immigrant inflows - it isolates that part of the variation that is predictable by the cumulative inflows up to time $t^{0}$. 
The combination of the slow adjustment process and the high degree of serial correlation in the country-of-origin distribution of immigrants means that the short-term response to new immigrant arrivals may overlap with the lagged response to past immigrant inflows. The conventional shift-share IV estimator used in the literature does not address this source of endogeneity and conflates these short- and long-term responses, making it both difficult to interpret and a biased estimator of $\beta_{1}$, the short-term wage impact of immigration.

We quantify the bias in estimating $\beta_{1}$ using the past settlement instrument by first noting that the labor market adjustment process is a function of all previous immigration and productivity shocks, as shown in Appendix A.1:

$$
\log k_{j t-1}^{*}-\log k_{j t-1}=\sum_{s=0}^{\infty}(1-\gamma)^{s}\left(m_{j t-s-1}+\frac{1}{1+\beta_{1}} \Delta \log \theta_{j t-s-1}\right)
$$

Substituting equation (10) into equation (9) gives

$$
\begin{aligned}
\Delta \log w_{j t}=\beta_{0}+ & \beta_{1} m_{j t} \\
& +\left[\epsilon_{j t}-\beta_{1} \gamma \sum_{s=0}^{\infty}(1-\gamma)^{s} m_{j t-s-1}\right. \\
& \left.+\left(\Delta \log \theta_{j t}-\frac{\beta_{1} \gamma}{1+\beta_{1}} \sum_{s=0}^{\infty}(1-\gamma)^{s} \Delta \log \theta_{j t-s-1}\right)\right]
\end{aligned}
$$

where, as in equation (9), the expression in square brackets is assumed to be unobserved to the econometrician. Using the past settlement instrument, $\widetilde{m}_{j t}$, to instrument for $m_{j t}$ and estimating equation (11) by two-stage least squares in a cross section at time $t$ gives

$$
\begin{aligned}
\operatorname{plim} \tilde{\beta}_{1}^{\mathrm{IV}}=\beta_{1} & {\left[1-\gamma \sum_{s=0}^{\infty}(1-\gamma)^{s} \frac{\operatorname{Cov}\left(\tilde{m}_{j t}, m_{j t-s-1}\right)}{\operatorname{Cov}\left(\tilde{m}_{j t}, m_{j t}\right)}\right.} \\
& \left.+\left(\frac{1}{\beta_{1}} \frac{\operatorname{Cov}\left(\tilde{m}_{j t}, \Delta \log \theta_{j t}\right)}{\operatorname{Cov}\left(\tilde{m}_{j t}, m_{j t}\right)}-\frac{\gamma}{1+\beta_{1}} \sum_{s=0}^{\infty}(1-\gamma)^{s} \frac{\operatorname{Cov}\left(\tilde{m}_{j t}, \Delta \log \theta_{j t-s-1}\right)}{\operatorname{Cov}\left(\tilde{m}_{j t}, m_{j t}\right)}\right)\right] .
\end{aligned}
$$


The asymptotic bias terms arise from the response of the labor market to past shocks. The first summation in square brackets is the response to immigration-induced supply shocks in the previous periods while the expression in parenthesis captures the labor market response to present and past local demand shocks. Both responses raise the marginal productivity of labor and lead to an upward bias in the IV estimate (assuming that $\beta_{1}$ is negative and less than 1 in absolute value). ${ }^{10}$

The terms in parentheses illustrate that demand shocks can generate bias even if they are not serially correlated. Intuitively, if local demand shocks trigger a prolonged adjustment process, immigrant shares must not only be uncorrelated with current demand shocks (the first term in parentheses) but also with past demand shocks (the summation term in parentheses). Choosing $t^{0}$ to be sufficiently lagged may therefore be advantageous even if the demand shocks themselves are not serially correlated, as we assume in our model. As this is a common strategy in the literature, we assume below that $t^{0}$ is sufficiently lagged so that $\widetilde{m}_{j t}$ is uncorrelated with the current adjustment to past demand shocks, i.e. we will assume that the terms in parentheses are equal to zero.

The bias from lagged supply shocks (the first summation in brackets) is harder to address. Note that we can rewrite the $\operatorname{Cov}\left(\widetilde{m}_{j t}, m_{j t-s-1}\right) / \operatorname{Cov}\left(\widetilde{m}_{j t}, m_{j t}\right)$ terms as ratios of the slope coefficients from regressions of lagged and current inflows, respectively, on the current instrument:

$$
\frac{\operatorname{Cov}\left(\widetilde{m}_{j t}, m_{j t-s-1}\right) / \operatorname{Var}\left(\widetilde{m}_{j t}\right)}{\operatorname{Cov}\left(\widetilde{m}_{j t}, m_{j t}\right) / \operatorname{Var}\left(\widetilde{m}_{j t}\right)}
$$

This ratio will be small if the instrument predicts current immigrant inflows at time $t$ substantially better than it predicts inflows in the previous periods. As we show below, this is unfortunately rarely the case in the U.S. context, where this ratio fluctuates around and sometimes exceeds one. The instrument is a good predictor for immigrant inflows in the intended period, but it is also a similarly good predictor for

\footnotetext{
${ }^{10}$ We have assumed that immigrant inflows occur as a "shock" to which local markets respond only in hindsight. If these inflows occur repeatedly in the same cities, however, their arrival might be anticipated. In Appendix A.2 we show that when future arrivals are anticipated, the disequilibrium bias becomes larger, and the estimates of the wage impact of immigrant are more positive, in the period after compositional changes occurred, when the response to unexpected arrivals in the previous period coincides with the updating of beliefs about future arrivals.
} 
previous inflows. The bias induced by these quantities is therefore potentially quite large. Lagging $t^{0}$ does not address this issue. ${ }^{11}$

The degree of adjustment, $\gamma$, may have little influence on the magnitude of the adjustment bias, however, if previous immigrant inflows are highly correlated over time. In the extreme case, if $\operatorname{Cov}\left(\tilde{m}_{j t}, m_{j t-s}\right)=\operatorname{Cov}\left(\tilde{m}_{j t}, m_{j t-1}\right)$ for all $s \geq 1$, and if we ignore the terms involving $\Delta \log \theta_{j t}$, which we have assumed to follow a random walk, then expression (12) simplifies to

$$
\operatorname{plim} \tilde{\beta}_{1}^{I V}=\beta_{1}\left[\frac{\operatorname{Cov}\left(\widetilde{m}_{j t}, m_{j t}\right)-\operatorname{Cov}\left(\widetilde{m}_{j t}, m_{j t-1}\right)}{\operatorname{Cov}\left(\tilde{m}_{j t}, m_{j t}\right)}\right]
$$

because $\lim _{t \rightarrow \infty} \gamma \sum_{s=0}^{t}(1-\gamma)^{s}=1$. This expression does not depend on the speed of convergence $\gamma$. Intuitively, it does not matter if a disequilibrium adjustment has been triggered by immigrant inflows in the previous period or in an earlier period if both are equally correlated with the instrument. In the U.S., the serial correlation in immigrant inflows is so extraordinarily high that the speed of convergence may therefore matter little. ${ }^{12}$

To illustrate the source of the adjustment bias more concretely, consider the following thought experiment. Imagine that the economy is in a spatial and dynamic equilibrium at some initial period $t=0$ and that immigrants are distributed non-uniformly across labor markets. If immigrant inflows occur at the next period $t=1$, they will be attracted to those labor markets in which the largest share of the initial immigrants from their country of origin live and also those areas that experience above-average labor demand shocks. Wages in labor market $j$ will change according to

$$
\Delta \log w_{j 1}=\beta_{0}+\beta_{1} m_{j 1}+\left[\Delta \log \theta_{j 1}+\epsilon_{j 1}\right]
$$

\footnotetext{
${ }^{11}$ Lagging the base period further may reduce the numerators in the ratios $\operatorname{Cov}\left(\widetilde{m}_{j t}, m_{j t-s-1}\right) / \operatorname{Cov}\left(\tilde{m}_{j t}, m_{j t}\right)$ but, by reducing its ability to predict inflows in period $t$, also the denominator. In principle, the bias may even be greater if the denominator shrinks more than the numerators. In the recent decades in the U.S., however, the ratio appears to be insensitive to the choice of base period $t^{0}$.

${ }^{12}$ What does matter, however, is the assumption that in the long run, immigrant inflows have no persistent effect on local relative wages. If the local recovery is only partial, the size of the bias in equation (13) would shrink proportionally. If immigration has instead a positive long-run effect on local wages (e.g. via agglomeration and density externalities, Peri 2016), the bias increases accordingly.
} 
If the instrument is uncorrelated with current demand shifts, $\Delta \log \theta_{j 1}$, the conventional IV estimator will consistently estimate $\beta_{1}$.

In response to the immigrant inflow, wages adjust at $t=2$ according to

$$
\Delta \log w_{j 2}=\beta_{0}+\beta_{1} m_{j 2}+\left[\Delta \log \theta_{j 2}-\beta_{1} \gamma\left(\log k_{j 1}^{*}-\log k_{j 1}\right)+\epsilon_{j 2}\right]
$$

where the term $\beta_{1} \gamma\left(\log k_{j 1}^{*}-\log k_{j 1}\right)$ reflects that local labor markets may still be adjusting to immigrant supply shocks as well as the demand shocks from $t=1$. Using the past settlement instrument, $\widetilde{m}_{j 2}$, to instrument for $m_{j 2}$ gives

$$
\operatorname{plim} \tilde{\beta}_{1 \mid t=2}^{I V}=\beta_{1}\left[1-\gamma\left(\frac{1}{1+\beta_{1}} \frac{\operatorname{Cov}\left(\tilde{m}_{j 2}, \Delta \log \theta_{j 1}\right)}{\operatorname{Cov}\left(\tilde{m}_{j 2}, m_{j 2}\right)}+\frac{\operatorname{Cov}\left(\tilde{m}_{j 2}, m_{j 1}\right)}{\operatorname{Cov}\left(\tilde{m}_{j 2}, m_{j 2}\right)}\right)\right]
$$

As equation (14) makes clear, the bias arising from the adjustment process can by itself cause the IV estimate of the impact of immigration to change from negative to positive if

$$
\left[\frac{1}{1+\beta_{1}} \frac{\operatorname{Cov}\left(\widetilde{m}_{j 2}, \Delta \log \theta_{j 1}\right)}{\operatorname{Cov}\left(\widetilde{m}_{j 2}, m_{j 1}\right)}+\frac{\operatorname{Cov}\left(\widetilde{m}_{j 2}, m_{j 1}\right)}{\operatorname{Cov}\left(\widetilde{m}_{j 2}, m_{j 2}\right)}\right]>\frac{1}{\gamma}
$$

Abstracting from any correlation of the instrument with the first period demand shock, we would estimate a positive effect of immigration even if the actual effect was negative if

$$
\gamma \frac{\operatorname{Cov}\left(\widetilde{m}_{j 2}, m_{j 1}\right)}{\operatorname{Var}\left(\widetilde{m}_{j 2}\right)}>\frac{\operatorname{Cov}\left(\widetilde{m}_{j 2}, m_{j 2}\right)}{\operatorname{Var}\left(\widetilde{m}_{j 2}\right)}
$$

We will be more likely to observe a change in sign if more of the adjustment to the first period shocks occurs in the second period ( $\gamma$ is higher) or if the instrument is more highly correlated with past inflows $\left(\operatorname{Cov}\left(\tilde{m}_{j 2}, m_{j 1}\right) / \operatorname{Var}\left(\tilde{m}_{j 2}\right)\right.$ is higher), relative to the first-stage coefficient on the instrument.

\section{Addressing the Dynamic Adjustment Process}

Our model illustrates the difficulty of consistently estimating the labor market impact of immigration using the past settlement instrument and suggests that the biases left unaddressed by the 
instrument are essentially an omitted variables problem. To see this more clearly, we can rewrite equation (11) as

$$
\Delta \log w_{j t}=\beta_{0}+\beta_{1} m_{j t}+\left(\sum_{k=1}^{\infty} \beta_{k+1} m_{j t-k}\right)+\left[\sum_{l=0}^{\infty} \delta_{l} \Delta \log \theta_{j t-l}+\epsilon_{j t}\right]
$$

where the quantity in square brackets is unobserved and $\beta_{k+1}=-\beta_{1} \gamma(1-\gamma)^{k-1}$ for $k \geq 1$. The adjustment process is a function of lagged immigrant inflows and present and lagged demand shocks. Previous empirical research has omitted the terms in parentheses. But we observe $m_{j t-k}$ at least up to some maximal lag, $\tau$, and can include these in the estimation. Just as $m_{j t}$ is correlated with $\Delta \log \theta_{j t}$, however, each of the $m_{j t-k}$ terms will be correlated with $\Delta \log \theta_{j t-k}$ (at a minimum), which appears in the disturbance term. The same kind of endogeneity issues that affect $m_{j t}$ in equation (11) also therefore affects its lags in equation $\left(11^{\prime}\right)$.

A natural solution to the endogeneity of the $m_{j t-k}$ terms is to instrument for them using lags of the past settlement instrument. As long as the base period, $t^{0}$, is sufficiently lagged, the instruments will be orthogonal to all of the demand shocks $\Delta \log \theta_{j t-k}$ and permit consistent estimation of the $\beta$ 's. In practical terms it is, of course, impossible to include an infinite number of $m_{j t-k}$ terms (and instrument for them), as equation $\left(11^{\prime}\right)$ suggests. The number of lags to include in estimation will depend on the speed of adjustment, $\gamma$, as well as data availability, and very likely varies by context (i.e. the frequency of data used, the outcome variable, and the country under examination). At issue is the time frame in which past shocks can arguably be ignored in equation $\left(11^{\prime}\right)$. Fewer lags may suffice if the included lags are highly correlated with and therefore control for earlier lags, or if $\gamma$ is large such that a greater share of the adjustment to shocks from period $t-1$ occurs in period $t$. With higher frequency data, the number of lags to include would surely be higher. Other strategies to address the adjustment bias are likely to be 
unsatisfactory. As already noted, further lagging $t^{0}$ does not address the correlation between the instrument and the lags $m_{j t-k} \cdot{ }^{13}$

As we present results from U.S. data at a decadal frequency, it seems reasonable to limit the number of included lags to 1 . In our setting, the included lag should also be approximately sufficient to control for higher order lags, because the distribution of country of origin shares has remained so stable in that period. By limiting the inclusion of past immigrant inflows to one lag, our model is now

$$
\Delta \log w_{j t}=\beta_{0}+\beta_{1} m_{j t}+\beta_{2} m_{j t-1}+\eta_{j t}
$$

The coefficient $\beta_{1}$, the usual coefficient of interest in the literature, captures the impact of immigration on wages in the short run and is likely negative, while the coefficient $\beta_{2}$ captures the longer-term reaction to past supply shocks and is expected to be positive. ${ }^{14} \mathrm{We}$ instrument the two endogenous variables with the two instruments,

$$
\widetilde{m}_{j t}=\sum_{o} \frac{M_{o j t^{0}}}{M_{o t^{0}}} \frac{\Delta M_{o t}}{L_{j t-1}} \text { and } \widetilde{m}_{j t-1}=\sum_{o} \frac{M_{o j t^{0}}}{M_{o t^{0}}} \frac{\Delta M_{o t-1}}{L_{j t-2}}
$$

in the two first-stage equations,

$$
m_{j t}=\pi_{10}+\pi_{11} \widetilde{m}_{j t}+\pi_{12} \widetilde{m}_{j t-1}+u_{j t}
$$

and

$$
m_{j t-1}=\pi_{20}+\pi_{21} \widetilde{m}_{j t}+\pi_{22} \widetilde{m}_{j t-1}+v_{j t}
$$

By controlling for $m_{j t-1}$ in equation (15) we address biases introduced by the adjustment process to past immigrant shocks. By instrumenting for $m_{j t}$ and $m_{j t-1}$ with $\widetilde{m}_{j t}$ and $\widetilde{m}_{j t-1}$ we address the endogeneity of current and past immigrant inflows to current and past labor demand shocks. ${ }^{15}$ To avoid a mechanical

\footnotetext{
${ }^{13}$ Validity checks that are useful for other reasons, such as whether $\widetilde{m}_{j t}$ is correlated with lagged wage growth (Peri 2016), would not reliably detect the adjustment bias problem because the absence of such a correlation is one of the possible consequences when the short-run impact of current immigrant inflows and the longer-term recovery to previous inflows overlap. While testing for parallel pre-trends is useful in a static setting with a one-time treatment, such tests are difficult to interpret in a dynamic setting with repeated shocks. Controlling for past wage growth in the wage regression does not suffice for the same reason.

${ }^{14}$ Specifically, in our model $\beta_{1}$ should be negative while $\beta_{2}$ should be positive and of similar magnitude if lagged adjustments are completed within about one decade or if immigrant inflows are highly serially correlated.

${ }^{15}$ It would be possible to transform our model into an autoregressive-distributed lag model to then apply dynamic
} 
relationship between $m_{j t-1}$ and $\widetilde{m}_{j t}$, that is between the local country-of-origin shares used to construct the instrument at time $t$ and local inflows at time $t-1, t^{0}$ should be chosen to be strictly prior to $t-1$.

If $\widetilde{m}_{j t}$ and its lag, $\widetilde{m}_{j t-1}$, are both constructed using the same base period $t^{0}$, the difference between the two instruments comes only from variation over time in the composition of national inflows. If this composition changes little from one period to the next, the instruments will be very highly correlated, and there may be little distinct variation in each to identify separately both first stage equations, which may suffer from a (joint) weak instrument problem in finite samples. The "multiple instrumentation" specification in equations (15) through (18) is therefore quite demanding on the data compared to instrumenting only for current inflows with $\tilde{m}_{j t}$. In periods in which the country of origin composition of migrants changes substantially, the instruments will less correlated with one another and less likely to suffer from the weak instrument problem. Our model also indicates that the adjustment bias is reduced in settings in which the overall rate of immigration has temporarily increased, or where originspecific push factors change the inflow rate of a particular origin group. ${ }^{16}$

\section{Data and Descriptive Statistics}

To demonstrate the problem and our solution, we use data from the 1960-2000 U.S. Censuses and the merged 2007-2011 American Community Surveys (ACS), all obtained through IPUMS (Ruggles, et al. 2015). For convenience, we will refer to the merged ACSs as the year 2010. We define an immigrant as a person born in a country other than the U.S. (excluding outlying U.S. territories) and a newly-arrived immigrant as a foreign-born person that immigrated during the last decade. We divide immigrants into 39

panel data methods (Bond 2002). This approach is less attractive with low frequency data, however, and we do not observe a sufficient number of lags of the dependent variable for the 1970s. Instead, our model points to a more direct way to address the endogeneity of current and past immigrant inflows.

${ }^{16}$ The use of push factors is typically motivated by the desire to break the potential endogeneity of national inflows to local conditions - for example, more Mexicans may enter the United States if the California labor market is strong. They may, under some conditions, also reduce the problems that we describe here, however, if the push factors trigger immigrant flows that are very different from previous inflows. 
countries and regions of origin. ${ }^{17}$ In descriptive results that use data that goes back to the 1940 Census, we use the same 17 countries and regions that were used by Card (2001) because of the limited information on countries of origin in those data.

The entire immigrant populations by origin and local area are used in the construction of the past settlement instrument. We conduct our analysis across metropolitan statistical areas (MSAs). ${ }^{18}$ MSAs are the standard unit of analysis in the existing literature and, because of their better comparability over time, are also the baseline unit in our analysis. We include in the analysis all MSAs that can be identified in all Censuses, use data on finer spatial units to make their boundaries as consistent over time as possible, and finally exclude three MSAs in which boundary changes were particularly large between the 1960, 1970, and 1980 Censuses, and for which finer information cannot be used to make them more consistent. ${ }^{19}$ This leaves us with a sample of 109 MSAs.

Our outcome variable is the average log weekly wage in the native labor force in an area. We restrict our wage sample to those who are 18 to 64 years of age and have 1 to 40 years of potential experience (age minus expected age at completion of formal schooling) and drop those who currently attend school, who live in group quarters, or who are self-employed. To reduce the influence of outliers (some wages are as low as, or below, one dollar per week) we drop individuals who wages are in the bottom and top percentile in each census year. Dropping the top percentile matters little, while the choice of cut-off point at the bottom has a non-negligible but, as we will show, limited, effect on our estimates.

${ }^{17}$ We separately include each country of origin with at least 5,000 observations in the 1990 census, except Cambodia, Iran, Laos, Thailand, and Vietnam, which were not separately coded in all Censuses. All remaining countries of origin are merged into the regions Latin America, Western Europe, Eastern Europe, Asia, Africa, Australia and New Zealand, and Others. Countries that split or merged after 1970 (the USSR, Yugoslavia, Czechoslovakia, and Germany) are coded as the merged unit throughout (e.g. the separate states of the Russian Federation continue to be coded as one unit after the breakup as the USSR, and West and East Germany are merged prior to 1990). Hong Kong and Taiwan are coded as part of China.

${ }^{18}$ Results using Commuting Zones as the geographic unit of observation are shown in Appendix B. The definition of commuting zones is based on Tolbert and Sizer (1996), and applied to Censuses using codes provided by Autor and Dorn (2013).

19 These are Bridgeport and New-Haven-Meriden, CT, and Worcester, MA. For all three, their total recorded populations more than triple between the 1960 and 1970 Censuses, and then shrink again by more than two-thirds in the 1980 Census. No other MSA comes close to an equally problematic pattern in the data. 
To address composition bias from changes in the skill and demographic characteristics of workers, we residualize wages using separate national-level regressions for each census year that control for six education levels (high school dropout, high school degree, some college but no degree, bachelor degree, master degree, and professional or doctoral degree), 40 potential experience levels, gender interacted with marital status, three races (white, black, and other), and nine U.S. Census divisions.

We show the characteristics of immigrant inflows by decade in Table 1 . The first row shows the immigrant share of the population, which has risen steadily from its low of 5.2 percent in 1970 to 13.6 percent in 2010. In Panel A, we show the share of new arrivals (those who entered the U.S. in the 10 years prior to the year of observation), the average share of new arrivals in 109 MSAs, as well as the standard deviation and coefficient of variation in new arrivals shares across those same MSAs. The coefficient of variation of the share of recent arrivals by MSA shrunk by one half between 1970 and 2010, indicating that immigrants were more geographically dispersed in earlier decades.

Panel B of Table 1 illustrates changes in the patterns of the country-of-origin distribution, which changed substantially in the 1970s. In addition to push factors like the Cuban Revolution and the Vietnam War that would have affected the origin of refugees, both the enactment in July 1968 of the 1965 Immigration and Nationality Act (Hatton 2015) and the ending of the Bracero agricultural worker program (Massey and Pren 2012) likely changed the ability to emigrate to the U.S. and the incentives for such migration for workers from different countries than had sent migrants previously. ${ }^{20}$ Among new arrivals in the 1970 Census (i.e. those who arrived in the 1960s, only a small minority of which arrived after the change in admissions policy was implemented in 1968), 41 percent were of Canadian or European origin, while in 1980 (those arriving in the 1970s, after the policy change) the corresponding share was only 17 percent. At the same time, the share of Latin Americans and Asians among the newly-arrived rose from 54 percent for those arriving in the 1960 s to 75 percent for those arriving in the 1970s. Since 1970, the

\footnotetext{
${ }^{20}$ The Immigration and Nationality Act replaced the national origins quotas, which favored British, German, and Irish immigrants, with a less discriminatory system. Congress did not intend to trigger radical changes in immigration patterns, and did not expect the sudden and dramatic shift in the origin composition (Hatton 2015).
} 
country-of-origin distribution has remained highly stable, however, and there are no similarly large compositional changes during the subsequent three decades.

We show the serial correlation from one decade to the next in the national composition of inflows in Panel $\mathrm{C}$ of Table 1. The first row shows the correlation in the shares of all 38 origins (excluding "Other"). The correlation in country of origin shares between those arriving in the 1960s and those arriving in the $1970 \mathrm{~s}$ is 0.59 while the correlation is between 0.96 and 0.99 in subsequent decades. In the next row, we find a similar pattern if we exclude Mexicans. In the last row, we show the correlation in immigrant stocks for all decades from 1950 to 2010 (because we cannot identify new immigrants prior to the 1970 Census). These results confirm that the 1970s witnessed a unique break in the country-of-origin composition of immigrants. The immigrant stocks in 1970 and 1980 have a correlation coefficient of 0.65 , while the three earlier pairwise correlations are all above 0.94 and those afterwards are at least 0.90 .

These patterns are illustrated in Figure 1, where we plot the country-of-origin shares in one decade with the same share in the subsequent decade. In each row, the left-hand graphs show all 39 country-of-origin groups while those on the right exclude Mexico. The first row plots the 1960 arrivals (from the 1970 Census) vs. the 1970 arrivals (from the 1980 Census). The second row plots the 1970 arrivals vs. the 1980 arrivals (from the 1990 Census), and so on. The correlation is clearly stronger after the 1970 s.

\section{Estimating the Impact of Immigration on Natives' Wages}

Our data allow us to estimate the wage impact of recent immigrant arrivals in the U.S. for five different decades, or four decades when controlling for the lagged inflow rate. 


\section{OLS and Conventional IV Estimates}

As a benchmark, in Panel A of Table 2 we present OLS estimates of equation (9) where the dependent variable is the decadal growth in residualized log wages of all workers aged 18 to 64 (subject to the other sample restrictions described above) and the units of observation are MSAs. While some of the literature has focused only on men, we include all workers. ${ }^{21}$ We estimate the model separately for each decade from 1960s to the 2000s. Panel B presents the corresponding IV estimates, together with the firststage coefficient on the past settlement instrument as defined in equation (1). The instruments are constructed with $t^{0}$ defined as the previous Census year. We also report the first stage $R^{2}$.

Both the OLS and IV estimates are positive for some decades. Selection may generate an upward bias in the OLS estimates and, once we instrument the immigrant inflow rate using the past settlement instrument, the estimates indeed tend to be more negative. The differences are modest, however, and the IV estimate for the 1980s (using the 1990 Census) is still positive and statistically significantly different from zero. The point estimates also differ substantially across the decades. ${ }^{22}$ Borjas, Freeman, and Katz (1997) and Borjas (1999) note that the spatial correlation approach yields quite different estimates for the 1970s and 1980s, and this variability extends to IV estimates based on Card's (2001) past settlement instrument, to more recent periods, and to different spatial definitions. While we use decadal data, this variability is unlikely to reflect differences in the timing of immigrant arrivals within each decade, because the share of inflows occurring in the second half of each decade remains quite stable (e.g. 57\% for the 1970 s vs $53 \%$ for the 1980 s).

It is only for the 1970 s (using the 1980 Census) that we find a more than marginally negative IV estimate of the effect on wages. As already noted, this was a period in which changes in the U.S. admission policy created a substantial shift in the country-of-origin composition of immigrant arrivals, leading to their distribution across MSAs being plausibly less related to their spatial distribution in the

\footnotetext{
${ }^{21}$ Estimating our results only for men yields similar results. These results are available from the authors by request.

${ }^{22}$ Estimates using Commuting Zones rather than MSAs are presented in Appendix Table B.1. and are similar.
} 
previous decade. In Panel A of Table 3 we report the correlations between actual immigrant inflows and the past settlement instrument and their respective lags. As expected, this correlation is lower for immigrant inflows in the 1970 s than in the later decades: 0.82 compared to 0.92 to 0.96 . This gap becomes larger when considering the instrument instead of actual inflows: 0.70 compared to 0.96 to 0.99 .

Given these magnitudes, serial correlation is an important issue regardless of the time period under consideration. There is at least some variation in the 1970s while in other decades both the actual inflows and the instrument are nearly perfectly correlated. Our theoretical argument implies that all the IV estimates in Table 2 are upward-biased, but it also suggests that this bias should be smallest in the 1970s (1980 Census) - exactly the period in which we find the most negative estimate. ${ }^{23}$

If we limit equation $\left(11^{\prime}\right)$ to having only one lag of immigrant inflows in the components of the disturbance term, we can estimate some of the key components of the disequilibrium bias. In particular, the "supply shock" bias is proportional to the ratio between the two pair-wise correlations of the instrument and lagged and current inflows. One might expect that the correlation of the instrument with current inflows (the denominator) would be larger than the correlation with lagged inflows (the numerator). As we show in Panel B of Table 3, this is unfortunately not the case. In the later decades, the instrument is more highly correlated with past inflows than with the current inflows it is supposed to predict. This is a natural pattern when the national composition changes very little, since past inflows are closer in time to the reference period $t^{0}$ used in the construction of the instrument. Lagging the reference period further weakens the predictive power of the instrument relative to time $t$, but does not substantially change this pattern, as can be seen by comparing the rows using $t-2$ as the base period (i.e. constructing the instrument from the base immigrant distribution two decades prior to the year of observation). The

\footnotetext{
${ }^{23}$ While the break in immigrant composition was likely not anticipated (see Hatton 2015, Massey and Pren 2012), worker and firms might have anticipated that the change in composition was permanent, generating a permanent shift in the spatial distribution of arrivals as well. In this case, our argument would also explain why the spatial correlation estimates are most positive in the 1980s (1990 Census). The question of whether workers and firms act on expectations plays a more important role in this argument than the question how expectations are exactly formed (see Appendix A.2). Because the spatial distribution of immigrants was so similar between the 1970s and 1980s, even naïvely extrapolating from the latter to the former would give quite reasonable predictions of local immigrant inflows.
} 
correlations between the actual inflows at $t$ and the instrument are still weaker than for the correlations when the actual inflows are measured at $t-1$.

Some studies in the literature combine spatial variation in immigrant inflows across areas with their density across skill groups. ${ }^{24}$ Depending on the outcome variable of interest, the explanatory variable may be the rate of immigration in a particular education group (Cortés, 2008, Hunt 2017), or the relative skill content of immigration (Card 2009, Lewis 2011) in an area. Panel C of Table 3 shows the immigration rates of high skilled (with some college or more) and low skilled (high school degree or less) workers, as well as the logarithm of the ratio of high skilled to low skilled immigrants. These measures show the same high degree of serial correlation as those in Panel A. The serial correlation in the skillspecific inflow rates and instruments is close to the corresponding values of the total rate, where it is modest in the 1970s and high in all later decades. The serial correlation in the log skill ratio is high in all periods and the disequilibrium problem will therefore also affect empirical strategies that exploit both spatial and skill-cell variation. ${ }^{25}$

“Multiple Instrumentation”: Reduced Form and First Stage Results

The "multiple instrumentation" procedure we introduced to address the bias due to the conventional shift-share instrument with the ongoing adjustment process of the labor market relies on innovations in the instrument between period $t-1$ and $t$ for identification. Periods in which there is little change in the flow variables from period to period will yield instruments that are highly correlated with one another. To gauge the degree of independent information in the two instruments, in Table 4 we present results from reduced form regressions of residualized wages (as in Table 2) on $\widetilde{m}_{j t}$ and $\widetilde{m}_{j t-1}$ as

\footnotetext{
${ }^{24}$ See Peri (2016) or Dustmann, Schönberg, and Stuhler (2016) for an overview. By using both spatial and skill-cell variation, one can difference out unobserved factors that lead to higher or lower wages of all workers in a city (see Card 2007). Only relative wage effects of immigration across skill groups are identified, however.

${ }^{25}$ The magnitude of the problem may be different, however. The assumption that average wages are mean reverting because labor demand is perfectly elastic in the long run is standard in the literature (even though wage differences between cities are persistent, see Moretti 2011), but differences in local skill-specific wages may be more persistent.
} 
defined in equations (16) for the 1970s through the 2000s. In creating the instruments, we choose $t^{0}$ to be 20 years prior to the Census year in which we observe wages to avoid, as already noted, a mechanical relationship between $\tilde{m}_{j t}$ and $m_{j t-1}$, particularly the disturbance term in equation (15), while also keeping the predictive power of the instruments as high as possible. As in all of the regression results in previous tables, we present heteroskedasticity-consistent standard errors.

For each decade, we also report the Kleibergen-Paap (2006) rk LM statistic for underidentification, which tests the null hypothesis that the rank of the matrix formed from the coefficient vectors from the first stage regressions is equal to 1 against the alternative that it is equal to 2 . That is, the statistic is informative about the degree of linear dependence between the estimated coefficients in equation (14) and those in equation (15) and indicates how different the predicted values from the two first stage regressions will be. Although the Kleinbergen-Paap statistic along with the reduced form coefficients will be informative about the degree to which the second stage is identified, we also report the first stage coefficients and the conventional first stage $F$ test (Bound, Jaeger, and Baker 1995) for the joint significance of the instruments in each equation separately.

We find a statistically significant reduced form relationship only in the 1970 s, where the instrument has a negative effect on wages and the lagged instrument has a positive effect on wages. None of the coefficients in the reduced form regressions from the other decades are statistically significant, although looking at the first stage regressions individually would not necessarily lead one to conclude that there are identification problems in the 1990 s and 2000s, as the first stage $F$ statistics are reasonably large and/or the first stage coefficients are statistically significant. As expected, only in the 1970s do we reject the null hypothesis of underidentification with the Kleinbergen-Paap statistic. The rest of our analysis is therefore focused on estimating the impact of immigration in the 1970s. 
“Multiple Instrumentation”: Second-stage Results

We estimate the impact of immigration in 1970s, the only decade in which there is enough independent information in the past settlement instrument and its lag to identify the second stage equation, and report our estimates in Table $5 .{ }^{26}$ We report different specifications, varying the definition of the outcome variable, the weighting scheme, or the inclusion of control variables in columns (1) to (6). For comparison, we report the conventional (single) IV estimate of the effect of immigrant inflows in Panel A. These results differ from those for the 1970s in Table 2 because, to be consistent with the multiple instrument procedure, we construct the instrument by using immigrant shares in 1960 rather than in 1970. We then show the estimates of the effect of immigrant inflows and lagged immigrant inflows on residualized wages using equation (13) in Panel B and the corresponding reduced-form estimates in Panel C. Our model provides clear predictions on the signs of the coefficients: the (presumably negative) coefficient on the 1970s inflows captures the wage impact of recent arrivals in the short run while the (presumably positive) coefficient on the 1960s inflows captures the longer-term reaction to local shocks.

We find that the impact of recent immigrant arrivals on natives' wages is indeed negative and statistically significant. In our baseline specification in Panel B, column (1), the impact of a one-percent (as a share of the local labor force) immigrant inflow is estimated to reduce average wages by about 0.7 $\log$ points. This estimate is substantially more negative than the corresponding conventional IV estimate in column (1), Panel A, consistent with our expectation that estimates that do not control for the adjustment to past immigrant shocks are biased upward. In column (1), we also find a positive and statistically significant coefficient on the predicted lagged immigrant inflow, in keeping with our expectation that this coefficient captures the longer-term adjustment of local labor markets to local supply shocks. In absolute terms, this coefficient is nearly as large as the coefficient on current inflows, suggesting that local wages

\footnotetext{
${ }^{26}$ As in with all regression results in the paper, we report heteroskedasticity-robust standard errors in Table 5 . These may be downward biased, however, because of small samples. Conventional estimates of the standard error are larger, but the coefficient estimate on recent arrivals remains significant at the 1 or 5 percent level in all specifications.
} 
do eventually recover from an immigration-induced supply shock. These estimates capture only the impact on local wages relative to other areas, however, and immigration may have a positive or negative effect over time on the national labor market as local labor markets spatially equilibrate. We get similar results when we trim an additional 4 percent from the bottom of the wage distribution in column (2). Other choices related to the construction of our variables, such as the use of current or lagged population as denominator when measuring the immigrant inflow rate, yield similar results and are available from the authors by request.

To this point we have weighted both small and large MSAs equally in our analysis. Some spatial correlation studies (e.g. Borjas 2006, Card 2009) weight MSAs by population, however. Solon, Wooldrige, and Haider (2015) note that the justification for weighting by absolute populations is not clear, as it may neither help in the estimation of population-average causal effects nor increase efficiency. ${ }^{27}$ In column (3), we present results where we weight the regressions by the population. This does somewhat reduce the standard errors, but also reduces both the conventional IV estimates in Panel A and the double instrument results in Panel B, such that none of the estimates are statistically significant. Because the variance of the dependent variable declines approximately linearly in the log of population, we present results in column (4) that are weighted by this quantity. We get results that are nearly identical to the unweighted results in column (1). We conclude that (properly) weighting makes little difference to the results.

A further concern is that different industry structures across MSAs might lead to a potential correlation between the past settlement instrument and changes in local labor demand from industryspecific or sectoral demand shifts. In column (5) we include as a control variable a Bartik (1991) shifter to control for local wage changes as predicted by the lagged 2-digit industry composition. The results change little as do those that include the local manufacturing or other industry shares, which are not shown but are

\footnotetext{
${ }^{27}$ Since all but three MSAs in our analysis have populations above 100,000 , individual-level uncertainty is unlikely to be an important factor in our sample, and heteroskedasticity of the error term with respect to population size appears limited. We do use weights in the commuting zone analysis in Appendix Tables B.1 and B.2, as many commuting zones have quite small populations.
} 
available from the authors by request. ${ }^{28}$ Controlling for Census division fixed effects in column (6), which would net out region-specific wage trends, only strengthens both the first stage and second stage effects. Because our wage measure already is net of Census division fixed effects, the difference between column (1) and column (6) is solely due to controlling for region-specific trends in the regressors. ${ }^{29}$

Our results suggest that the estimated short-term effect of immigration is substantially more negative once we control for the adjustment to previous immigrant inflows and that our results are generally robust to common specification choices. The results support our core argument that estimates based on the conventional shift-share instrument are upwardly biased estimates of the short-run effect, arising from the high correlation between current and past immigrant inflows.

Second-stage Results: Heterogeneity Across Subgroups

The distributional consequences of immigration are a common concern (Borjas, Freeman, and Katz 1992, Jaeger 1996, Card 2009). Immigrant inflows are not uniformly distributed across skills, and the effects on natives are likely to be concentrated in those skill groups that more directly compete with immigrant arrivals. In the U.S., immigration had a bigger effect on labor supply at lower skill levels (Jaeger 1996), in particular once we take into account that new arrivals tend to work in systematically less skilled occupations than natives with the same observed education and experience levels (e.g. Borjas 1985, Dustmann 1993). ${ }^{30}$ With regard to our model, we would also be concerned if we estimated the

\footnotetext{
${ }^{28}$ A particular concern could be the large swings of prices and wages in the oil industry. While its local employment share is a highly significant predictor, it does not have an important effect on the coefficients on immigrant inflows.

${ }^{29}$ We present second-stage results using Commuting Zones instead of MSAs in Appendix Table B.2. This spatial definition is ill-suited for our purpose and decade of interest, but the pattern of coefficients remains comparable (although they are estimated less precisely). Only about 400 county groups are identified in the 1970 IPUMS Census, more than $50 \%$ of which overlap with multiple Commuting Zones. The measured wage change in a Commuting Zone between the 1970 and 1980 Census may therefore reflect changes in its underlying area definition.

${ }^{30}$ Dustmann, Schönberg and Stuhler (2016) impute the effective skills of U.S. immigrants based on their observed distribution across occupation-wage cells. While immigrant arrivals in the 1970s had similar observed skills as natives, their effective skills are substantially lower. These results are available from the authors by request.
} 
largest impact on wages among workers who are less likely to face labor market competition from immigrants.

We report IV estimates of the impact of immigration on native's wages in the 1970s for various subgroups using our double instrument procedure in Table 6. For comparison, the first row repeats our estimate for all workers from Table 5. In the second row, we restrict the sample only to male workers, which yields point estimates that are similar to those for all workers, but are statistically significant only at the 10 percent level ( $p$-value $=0.053)$. In the third and fourth rows, we stratify by education and find that the short-term impact on wages is greater for natives with a high school degree or less and in rows and in rows 5 through 7 we find that young workers are most affected. Focusing on young and less educated workers in row 8, the estimated short-run impact is even higher.

While we do not want to emphasize any of the point estimates as representing a definitive estimate of the impact of immigration, the overall pattern of results is consistent with the expectation that we should see the greatest impact on wages in those groups with which immigrants compete more strongly. By isolating recent immigrant arrivals from previous inflows, we use a substantially narrower source of variation than the previous literature, and some estimates are relatively imprecise. These results provide some evidence, however, that our empirical strategy captures the short run impact of immigration and not of other local shocks that happen to have a similar spatial distribution.

\section{Conclusions}

Estimating the impact of immigration is notoriously one of the most difficult exercises in empirical economics. Immigrants' location choices are not random, and the economy may adjust in many different ways to a change in local factor supplies. To establish causal identification in spite of these issues, many of the existing studies of the short-term wage response use the past settlement instrument, a shift-share instrument that combines national inflows with the locational patterns of immigrants in a previous period. We showed that this approach is unlikely to identify a well-defined causal effect of 
interest when there is only limited change in the country-of-origin composition of immigrant inflows at the national level. In such a setting, the inflow rates of immigrants across cities will tend to be highly serially correlated. In recent decades in the U.S., the rates have been nearly perfectly correlated, with the same cities repeatedly receiving large inflows. As a consequence, the shift-share instrument predicts not only recent arrivals, but is also a great (and often better) predictor for arrivals in a previous decade.

The conventional IV estimator captures then not only the short-term response to recent immigrant arrivals, but also the longer-term adjustment processes that such arrivals may trigger. This compound effect is hard to interpret. How the estimator weights the short- and longer-term wage response will differ across applications, as the correlation of the instrument with its lag will differ. The longer-term estimates of the response of local wages itself is difficult to interpret, as it may reflect spatial adjustment processes that eventually affect also "control" areas that were not directly exposed to immigrant inflows.

To address these issues systematically we propose a revised "multiple instrument" estimation procedure that captures and separates both the initial wage response, and the longer-term adjustment of local relative wages to immigrant inflows. Decomposing immigrant inflows by origin groups rather than considering the overall inflow (Card 2001) is crucial for this strategy. In our data, this decomposition has little effect on the conventional (single) IV estimator, but using our multiple instrument procedure, it allows us to isolate innovations in local immigrant inflows that are caused by compositional changes at the national level.

Our proposed approach places a substantial demand on the data relative to the single instrument procedure, as the multiple instruments will typically be highly collinear. In the U.S. in recent decades there are insufficient innovations in the location choices of immigrants to distinguish their short and longterm impacts. Only in the 1970 s do we find a sufficient change in the composition of immigrant inflows to allow us to apply our revised estimator. Our estimates are more negative than many in the previous literature, suggesting that the initial wage impact of immigration on natives is potentially large. Our results also suggest, however, that much of this decline is reversed in later periods. Cities that received large (predicted) immigrant inflows in the 1960s, but smaller inflows during the 1970s, tend to experience a 
relative wage increase. Immigration may thus have little, if any, adverse effect on local relative wages in the longer run.

In practical terms, our results suggest that researchers wishing to use spatial variation to estimate the impact of immigration should be aware of longer-term adjustment processes and to control for them with lagged immigrant inflows, but instrumented with lagged past settlement instruments. Because the instruments are potentially highly collinear, researchers should check for underidentification or weak identification (e.g., with the Kleibergen-Papp 2006 rk LM statistic) and report reduced form results. Our example has focused on a setting in which including only one lag of immigrant inflows seems appropriate, but higher order lags should be included with higher frequency data.

Our procedure also applies more generally to shift-share instruments in other contexts. The common feature of shift-share IV strategies is the imputation of exogenous local shocks by multiplying aggregate "shifts" with local "shares" of industry, demographic or other compositions. Because the local shares component of this product will almost always be highly serially correlated, the problem we highlight will be present to some extent in any shift-share IV context that features dynamic adjustments and limited innovations in the aggregate components of the instrument. Our simple solution using multiple lags of the shock variable instrumented with lags of the conventional shift-share instrument addresses this issue. 


\section{References}

Acemoglu, Daron and Joshua Linn, "Market Size in Innovation: Theory and Evidence from the Pharmaceutical Industry," Quarterly Journal of Economics, 119 (2004), 1049-1090.

Acemoglu, Daron and Pascual Restrepo, "Robots and Jobs: Evidence from US Labor Markets," NBER Working Paper 23285, 2017.

Altonji, Joseph G. and David Card, "The Effects of Immigration on the Labor Market Outcomes of Lessskilled Natives," in Immigration, Trade and the Labor Market, John Abowd and Richard. Freeman, eds. (Chicago, University of Chicago Press: 1991).

Amior, Michael, "The Contribution of Foreign Migration to Local Labor Market Adjustment," Unpublished manuscript, Hebrew University, 2017.

Amior, Michael and Alan Manning, "The Persistence of Local Joblessness," Unpublished manuscript, Centre for Economic Performance, London School of Economics, 2017.

Amuedo-Dorantes, Catalina and Almudena Sevilla, "Low-Skilled Immigration and Parenting Investments of College-Educated Mothers in the United States: Evidence from Time-Use Data," Journal of Human Resources, 49 (2014), 509-539.

Autor, David H., and David Dorn, "The Growth of Low-Skill Service Jobs and the Polarization of the US Labor Market," American Economic Review, 103 (2013), 1553-97.

Autor, David H., David Dorn, and Gordon H. Hanson, "The China Syndrome: Local Labor Market Effects of Import Competition in the United States," American Economic Review, 103 (2013), 21212168 .

, "The China Shock: Learning from Labor-Market Adjustment to Large Changes in Trade," Annual Review of Economics, 8 (2016), 205-240.

Aydemir, Abdurrahman, and George J. Borjas, "Attenuation Bias in Measuring the Wage Impact of Immigration," Journal of Labor Economics, 29 (2011), 69-112.

Aydemir, Abdurrahman and Morat G. Kurdar, "Quasi-Experimental Impact Estimates of Immigrant Labor Supply Shocks: The Role of Treatment and Comparison Group Matching and Relative Skill Composition," IZA Discussion Paper No. 7161, 2013.

Barone, Guglielmo, Alessio D'Ignazio, Guido de Blasio, and Paolo Naticchioni, "Mr. Rossi, Mr. Hu and Politics. The Role of Immigration in Shaping Natives' Voting Behavior," Journal of Public Economics, 136 (2016), 1-13.

Bartel, Ann P., “Where Do the New U.S. Immigrants Live?” Journal of Labor Economics, 7 (1989), 37191.

Bartik, Timothy J., Who Benefits from State and Local Economic Development Policies? (Kalamazoo, MI: W.E. Upjohn Institute for Employment Research, 1991).

Bell, Brian, Francesco Fasani, and Stephen Machin, "Crime and Immigration: Evidence from Large Immigrant Waves," Review of Economics and Statistics, 95 (2013), 1278-1290.

Beaudry, Paul, David. A. Green, and Benjamin Sand, "Does Industrial Composition Matter for Wages? A Test of Search and Bargaining Theory," Econometrica, 80 (2012), 1063-1104.

Bianchi, Milo, Paolo Buonanno, and Paolo Pinotti, "Do Immigrants Cause Crime?" Journal of the European Economic Association, 10 (2012), 1318-1347.

Blanchard, Olivier. J., and Larry F. Katz, "Regional Evolutions," Brookings Papers on Economic Activity, 23 (1992), 1-76. 
Bond, Stephen R., "Dynamic Panel Data Models: A Guide to Micro Data Methods and Practice," Portuguese Economic Journal, 1 (2002), 141-162.

Bosetti, Valentina, Cristina Cattaneo, and Elena. Verdolini, "Migration of Skilled Workers and Innovation: A European Perspective," Journal of International Economics, 96 (2015), 311-322.

Bound, John, David A. Jaeger, and Regina M. Baker, "Problems with Instrumental Variables Estimation when the Correlation between the Instruments and the Endogenous Explanatory Variable is Weak," Journal of the American Statistical Association, 90 (1995), 443-450.

Borjas, George J., "Assimilation, Changes in Cohort Quality, and the Earnings of Immigrants," Journal of Labor Economics, 3 (1985), 463-489.

, "The Economic Analysis of Immigration," in Handbook of Labor Economics, Vol. 3A, Orley Ashenfelter, and David Card, eds. (Amsterdam: Elsevier, 1999).

"The Labor Demand Curve is Downward Sloping: Reexamining the Impact of Immigration on the Labor Market," Quarterly Journal of Economics, 118 (2003), 1335-1374.

, "Native Internal Migration and the Labor Market Impact of Immigration," Journal of Human Resources, 41 (2006), 221-258.

, Immigration Economics. (Cambridge, MA: Harvard University Press, 2014).

Borjas, George J., Richard B. Freeman, and Larry F. Katz, "How Much Do Immigration and Trade Affect Labor Market Outcomes?” Brookings Papers on Economic Activity, 28 (1997), 1-90.

Boustan, Leah P., "Was Postwar Suburbanization 'White Flight'? Evidence from the Black Migration," Quarterly Journal of Economics, 125 (2010), 417-443.

Braun, Sebastian Till and Henning Weber, "How Do Regional Labor Markets Adjust to Immigration? A Dynamic Analysis for Post-War Germany," Kiel Institute for the World Economy Discussion Paper No. 2025, 2016.

Calvet, Leon E., John Y. Campbell, and Paolo Sodini, "Fight or Flight? Portfolio Rebalancing by Individual Investors," Quarterly Journal of Economics, 124 (2009), 301-348.

Card, David, "Immigrant Inflows, Native Outflows, and the Local Labor Market Impacts of Higher Immigration," Journal of Labor Economics, 19 (2001), 22-64.

, "How Immigration Affects U.S. Cities," CReAM Discussion Paper Series 0711, Department of Economics, University College London, 2007.

, "Immigration and Inequality," American Economic Review, 99 (2009), 1-21.

Card, David, and John DiNardo, "Do Immigrant Inflows Leads to Native Outflows?" American Economic Review Papers and Proceedings, 90 (2000), 360-367.

Card, David and Giovanni Peri, "Immigration Economics: A Review," Journal of Economic Literature, 54 (2016), 1333-49.

Cascio, Elizabeth U., and Ethan G. Lewis, "Cracks in the Melting Pot: Immigration, School Choice, and Segregation," American Economic Journal: Economic Policy, 4 (2012), 91-117.

Cattaneo, Cristina., Carlo V. Fiorio, and Giovanni Peri, "What Happens to the Careers of European Workers When Immigrants 'Take Their Jobs'?” Journal of Human Resources, 50 (2015), 655693.

Chalfin, Aaron, "The Long-Run Effect of Mexican Immigration on Crime in US Cities: Evidence from Variation in Mexican Fertility Rates," American Economic Review Papers and Proceedings, 105 (2015), 220-25. 
Cohen-Goldner, Sarit, and M. Daniele Paserman, "The Dynamic Impact of Immigration on Natives' Labor Market Outcomes: Evidence from Israel," European Economic Review, 55 (2011), 1027-1045.

Cortés, Patricia, "The Effect of Low-Skilled Immigration on U.S. Prices: Evidence from CPI Data," Journal of Political Economy, 116 (2008), 381-422.

Cortés, Patricia, and Jessica Pan, "Foreign Nurse Importation and the Supply of Native Nurses," Journal of Health Economics, 37 (2014), 164-180.

Cortés, Patricia and José Tessada, "Low-Skilled Immigration and the Labor Supply of Highly Skilled Women," American Economic Journal Applied Economics, 3 (2011), 88-123.

D'Amuri, Francesco, and Giovanni Peri, "Immigration, Jobs, and Employment Protection: Evidence from Europe Before and During the Great Recession," Journal of the European Economic Association, 12 (2014), 432-464.

de Roux, Nicholas, Marcela Eslava, Santiago Franco, and Eric Verhoogen, "Using Exchange Rates to Estimate Production Functions: Evidence from Colombia," Unpublished manuscript, Columbia University, 2017.

Deaton, Angus, "Instruments, Randomization, and Learning about Development," Journal of Economic Literature, 48 (2010), 424-455.

Del Carpio, Ximena, Çağlar Özden, Mauro Testaverde, and Mathis Wagner, "Local Labor Supply Responses to Immigration," Scandinavian Journal of Economics, 117 (2015), 493-521.

Dustmann, Christian, "Earnings Adjustment of Temporary Migrants," Journal of Population Economics, 6 (1993), 153-68.

Dustmann, Christian, Francesca Fabbri, and Ian Preston, "The Impact of Immigration on the British Labour Market,” Economic Journal, 115 (2005), F324-F341.

Dustmann, Christian, Tommaso Frattini, Ian Preston, "The Effect of Immigration Along the Distribution of Wages," Review of Economic Studies, 80 (2013), 145-173.

Dustmann, Christian, and Albrecht Glitz, "How Do Industries and Firms Respond to Changes in Local Labor Supply?” Journal of Labor Economics, 33 (2015), 711-750.

Dustmann, Christian, and Ian Preston, "Comment: Estimating the Effect of Immigration on Wages," Journal of the European Economic Association, 10 (2012), 216-223.

Dustmann, Christian, Uta Schönberg, and Jan Stuhler, “The Impact of Immigration: Why Do Studies Reach Such Different Results?” Journal of Economic Perspectives, 30 (2016), 31-56.

, "Labor Supply Shocks, Native Wages, and the Adjustment of Local Employment," Quarterly Journal of Economics, 132 (2017), 435-483.

Eberts, Randall W., and Joe A. Stone, Wage and Employment Adjustment in Local Labor Markets. (Kalamazoo, MI: W.E. Upjohn Institute for Employment Research, 1992).

Edo, Anthony, "The Impact of Immigration on Wage Dynamics: Evidence from the Algerian Independence War," CEPII Research Center Working Paper 2017-13, 2017.

Facchini, Giovanni, Anna Maria Mayda, and Mariapia Mendola, "South-South Migration and the Labor Market: Evidence from South Africa," IZA Discussion Paper No. 7362, 2013.

Fairlie, Robert W. and Bruce D. Meyer, "The Effect of Immigration on Native Self-Employment," Journal of Labor Economics, 21 (2003), 619-650.

Farré, Lidia, Libertad González, and Francesc Ortega, "Immigration, Family Responsibilities and the Labor Supply of Skilled Native Women," B.E. Journal of Economic Analysis and Policy (Contributions), 11 (2011), 34. 
Fassio, Claudio, Sona Kalantaryan, and Alessandra Venturini, "Human Resources and Innovation: Total Factor Productivity and Foreign Human Capital,” IZA Discussion Papers No. 9422, 2015.

Fernández-Huertas Moraga, Jesús, Ada Ferrer-i-Carbonell, and Albert Saiz, "Immigrant Locations and Native Residential Preferences: Emerging Ghettos or New Communities," IZA Discussion Paper No. 11143, 2017.

Foged, Mette, and Giovanni Peri, "Immigrants' Effect on Native Workers: New Analysis on Longitudinal Data," American Economic Journal: Applied Economics, 8 (2016), 1-34.

Forlani, Emanuele, Elisabetta Lodigiani, and Concetta Mendolicchio, "Impact of Low-Skilled Immigration on Female Labour Supply," Scandinavian Journal of Economics, 117 (2015), 452492.

Frattini, Tommaso, "Immigration and Prices in the UK," Unpublished manuscript, University of Milan, 2008.

Fulford, Scott L., Ivan Petkov, and Fabio Sciantarelli, "Does It Matter Where You Came From? Ancestry Composition and Economic Performance of US Counties, 1850-2010," Unpublished manuscript, Boston College, 2017.

Furtado, Delia, and Heinrich Hock, "Low Skilled Immigration and Work-Fertility Tradeoffs among High Skilled US Natives," American Economic Review Papers and Proceedings, 100 (2010), 224-28.

Ganguli, Ina, "Immigration and Ideas: What did Russian Scientists 'Bring' to the United States?" Journal of Labor Economics, 33 (2015), S257-S288.

Giuntella, Osea, and Fabrizio Mazzonna, "Do Immigrants Improve the Health of Natives?" Journal of Health Economics, 43 (2015), 140-153.

Goldsmith-Pinkham, Paul, Isaac Sorkin, and Henry Swift, "Bartik Instruments: What, When, Why and How," Unpublished manuscript, Stanford University, 2017.

González, Libertad, and Francesc Ortega, "How Do Very Open Economies Adjust to Large Immigration Flows? Evidence from Spanish Regions," Labour Economics, 18 (2011), 57-70.

Greenaway-McGrevy, Ryan, and Kyle K. Hood, "Worker Migration or Job Creation? Persistent Shocks and Regional Recoveries," Journal of Urban Economics, 96 (2016), 1-16.

Graetz, George and Guy Michaels, "Robots at Work," Unpublished manuscript, London School of Economics, 2017.

Greenstone, Michael, Alexandre Mas, and Hoai-Luu Nguyen, "Do Credit Market Shocks Affect the Real Economy? Quasi-Experimental Evidence from the Great Recession and 'Normal' Economic Times," NBER Working Paper No. 20704, 2014.

Hatton, Timothy J., "United States Immigration Policy: The 1965 Act and its Consequences," Scandinavian Journal of Economics, 11 (2015), 347-368.

Hatton, Timothy J., and Massimiliano Tani, "Immigration and Inter-Regional Mobility in the UK, 19822000,” Economic Journal, 115 (2005), F342-F358.

Hunt, Jennifer, "The Impact of Immigration on the Educational Attainment of Natives," Journal of Human Resources, 52 (2017), 1060-1118.

Hunt, Jennifer, and Marjolaine Gauthier-Loiselle, "How Much Does Immigration Boost Innovation?" American Economic Journal: Macroeconomics, 2 (2010), 31-56.

Iranzo, Susana and Giovanni Peri, "Schooling Externalities, Technology, and Productivity: Theory and Evidence from U.S. States," Review of Economics and Statistics, 91 (2009), 420-431. 
Jaeger, David A., "Skill Differences and the Effect of Immigrants on the Wages of Natives," Bureau of Labor Statistics Working Paper Number 273, 1996.

, "Green Cards and the Location Choices of Immigrants in the United States, 1971-2000," Research in Labor Economics, 27 (2007), 131-183.

Kasy, Maximilian, "Identification in a Model of Sorting with Social Externalities and the Causes of Urban Segreation," Journal of Urban Economics, 85 (2015), 16-33.

Kerr, William R., and William F. Lincoln, "The Supply Side of Innovation: H-1B Visa Reforms and U.S. Ethnic Invention," Journal of Labor Economics, 28 (2010), 473-508.

Kleibergen, Frank, and Richard Paap, "Generalized Reduced Rank Tests Using the Singular Value Decomposition," Journal of Econometrics, 33 (2006):97-126.

Kling, Jeffrey R., "Incarceration Length, Employment, and Earnings," American Economic Review, 96 (2006), 863-876.

Kovak, Brian K., "Regional Effects of Trade Reform: What Is the Correct Measure of Liberalization?" American Economic Review, 103 (2013), 1960-1976.

Kugler, Adriana, and Mutlu Yuksel, "Effects of Low-Skilled Immigrants on U.S. Natives: Evidence from Hurricane Mitch,” NBER Working Paper 14293, 2008.

Lafortune, Jeanne, "Making Yourself Attractive: Pre-Marital Investments and the Returns to Education in the Marriage Market," American Economic Journal: Applied Economics, 5 (2013), 151-178.

Lalonde, Robert J., and Robert H. Topel, "Labor Market Adjustments to Increased Immigration," in Immigration, Trade and the Labor Market, John Abowd and Richard. Freeman, eds. (Chicago, University of Chicago Press: 1991).

Lewis, Ethan, "Immigration, Skill Mix, and Capital Skill Complementarity," Quarterly Journal of Economics, 126 (2011), 1029-1069.

Llull, Joan, "The Effect of Immigration on Wages: Exploiting Exogenous Variation at the National Level," forthcoming, Journal of Human Resources, 2018.

Machin, Stephen and Richard Murphy, "Paying Out and Crowding Out? The Globalization of Higher Education," Journal of Economic Geography, 17 (2017), 1075-1110.

Malchow-Møller, Nikolaj, Jakob R. Munch, and Jan Rose Skaksen, "Do Immigrants Affect Firm-Specific Wages," Scandinavian Journal of Economics, 114 (2012),1267-1295.

Massey, Douglas S., and Karen A. Pren, "Unintended Consequences of US Immigration Policy: Explaining the Post-1965 Surge from Latin America," Population and Development Review, 38 (2012), 1-29.

McHenry, Peter, "Immigration and the Human Capital of Natives," Journal of Human Resources, 50 (2015), 34-71.

Monras, Joan, "Immigration and Wage Dynamics: Evidence from the Mexican Peso Crisis," IZA Discussion Paper 8924, 2015.

Moreno-Galbis, Eva, and Ahmed Tritah, "The Effects of Immigration in Frictional Labor Markets: Theory and Empirical Evidence from EU Countries," European Economic Review, 84 (2016), 76-98.

Moretti, Enrico, "Local Labor Markets," in Handbook of Labor Economics, Vol. 4B, Orley Ashenfelter, and David Card, eds. (Amsterdam: Elsevier, 2011).

Nakamura, Emi, and Jón Steinsson, "Fiscal Stimulus in a Monetary Union: Evidence from US Regions," American Economic Review, 104 (2014), 753-792. 
National Academy of Sciences, The Economic and Fiscal Consequences of Immigration, Panel on the Economic and Fiscal Consequences of Immigration, Fran D. Blau and Christopher Mackie, eds. (Washington, DC: The National Academies Press, 2017).

Nunn, Nathan, and Nancy Qian, "US Food Aid and Civil Conflict," American Economic Review, 104 (2014), 1630-1666.

Orrenius, Pia M., and Madeline Zavodny, "Does Immigration Affect Wages? A Look at Occupation-Level Evidence," Labour Economics, 14 (2007), 757-773.

, "Does Immigration Affect Whether US Natives Major in Science and Engineering?" Journal of Labor Economics, 33 (2015), S79-S108.

Ortega, Javier, and Gregory Verdugo, "The Impact of Immigration on the French Labor Market: Why So Different?" Labour Economics, 29 (2014), 14-27.

Ottaviano, Gianmarco I. P., and Giovanni Peri, "Cities and Cultures," Journal of Urban Economics, 53 (2005), 304-337.

, "The Economic Value of Cultural Diversity: Evidence from US Cities," Journal of Economic Geography, 6 (2006), 9-44.

Ottaviano, Gianmaro I. P., Giovanni Peri, and Greg C. Wright, "Immigration, Offshoring, and American Jobs," American Economic Review, 103 (2013), 1925-1959.

"Immigration, Trade and Productivity in Services: Evidence from U.K. Firms," NBER Working Paper 21200, 2015.

Özden, Çağlar, and Mathis Wagner, "Immigrants versus Natives? Displacement and Job Creation," Unpublished manuscript, Boston College, 2016.

Peri, Giovanni, "Rethinking the Area Approach: Immigrants and the Labor Market in California," Journal of International Economics, 84 (2011), 1-14.

, "The Effect of Immigration on Productivity: Evidence from U.S. States," Review of Economics and Statistics, 94 (2012), 348-358.

, "Immigrants, Productivity, and Labor Markets," Journal of Economic Perspectives, 30 (2016), 330.

Peri, Giovanni, Kevin Shih, and Chad Sparber, "STEM Workers, H-1B Visas, and Productivity in US Cities," Journal of Labor Economics, 33 (2013), S225-S255.

Peri, Giovanni, and Chad Sparber, "Task Specialization, Comparative Advantages, and the Effects of Immigration on Wages," American Economic Journal: Applied Economics, 1 (2009), 135-169.

Pischke, Jörn-Steffen and Johannes Velling, "Employment Effects of Immigration to Germany: An Analysis Based on Local Labor Markets," Review of Economics and Statistics, 79 (1997), 594604.

Piveteau, Paul, and Gabriel Smagghue, "Estimating Firm Product Quality Using Trade Data," Unpublished manuscript, Johns Hopkins University, 2017.

Piyapromdee, Suphanit, "The Impact of Immigration on Wages, Internal Migration, and Welfare," Unpublished manuscript, University College London, 2017.

Ransom, Tyler, and John V. Winters, "Do Foreigners Crowd Natives Out of STEM Degrees and Occupations? Evidence from the U.S. Immigration Act of 1990," IZA Discussion Papers 9920, 2016.

Reed, Deborah and Sheldon Danziger, "The Effect of Recent Immigration on Racial/Ethnic Labor Market Differentials," American Economic Review Papers and Proceedings, 97 (2007), 373-377. 
Ruggles, Steven, Katie Genadek, Ronald Goeken, Josiah Grover, and Matthew Sobek, Integrated Public Use Microdata Series: Version 6.0 [Machine-readable database], University of Minnesota, 2015.

Saiz, Albert, "Immigration and Housing Rents in American Cities," Journal of Urban Economics, 61 (2007), 345-371.

Smith, Christopher L., "The Impact of Low-Skilled Immigration on the Youth Labor Market," Journal of Labor Economics, 30 (2012), 55-89.

Solon, Gary, Steven J. Haider, and Jeffrey M. Wooldridge, "What Are We Weighting For?" Journal of Human Resources, 50 (2015), 301-316.

Tolbert, Charles M., and Molly Sizer, "U.S. Commuting Zones and Labor Market Areas: A 1990 Update," Rural Economy Division, Economic Research Service, U.S. Department of Agriculture, Staff Report No. AGES-9614, 1996.

Topel, Robert H., "Local Labor Markets," Journal of Political Economy, 94 (1986), S111-S143.

Wilson, Daniel J., "Fiscal Spending Jobs Multipliers: Evidence from the 2009 American Recovery and Reinvestment Act," American Economic Journal: Economic Policy, 4 (2012), 251-282.

Wozniak, Abigail, and Thomas J. Murray, "Timing is Everything: Short-Run Population Impacts of Immigration in US Cities," Journal of Urban Economics, 72 (2012), 60-78. 


\section{Appendix A.1: Labor Market Adjustments}

First differencing equation (7) gives the change in the optimal level of the capital-labor ratio, which is solely a function of labor demand shocks:

$$
\log k_{j t}^{*}-\log k_{j t-1}^{*}=\frac{1}{1-\alpha} \Delta \log \theta_{j t}
$$

Subtracting equation (8) from this expression gives

$$
\log k_{j t}^{*}-\log k_{j t-1}^{*}-\left(\log k_{j t}-\log k_{j t-1}\right)=m_{j t}+\frac{1}{1-\alpha} \Delta \log \theta_{j t}-\gamma\left(\log k_{j t-1}^{*}-\log k_{j t-1}\right) .
$$

such that

$$
\log k_{j t}^{*}-\log k_{j t}=m_{j t}+\frac{1}{1-\alpha} \Delta \log \theta_{j t}+(1-\gamma)\left(\log k_{j t-1}^{*}-\log k_{j t-1}\right)
$$

Lagging one period, iterating backward, and noting that $\beta_{1}=-\alpha$, we have

$$
\begin{aligned}
\log k_{j t-1}^{*}-\log k_{j t-1}= & m_{j t-1}+\frac{1}{1+\beta_{1}} \Delta \log \theta_{j t-1}+(1-\gamma)\left(\log k_{j t-2}^{*}-\log k_{j t-2}\right) \\
= & m_{j t-1}+\frac{1}{1+\beta_{1}} \Delta \log \theta_{j t-1}+(1-\gamma)\left(m_{j t-2}+\frac{1}{1+\beta_{1}} \Delta \log \theta_{j t-2}\right)+ \\
& (1-\gamma)^{2}\left(\log k_{j t-3}^{*}-\log k_{j t-3}\right) \\
= & \cdots \\
= & \sum_{s=0}^{\infty}(1-\gamma)^{s}\left(m_{j t-s-1}+\frac{1}{1+\beta_{1}} \Delta \log \theta_{j t-s-1}\right) .
\end{aligned}
$$




\section{Appendix A.2: The Adjustment Process with Anticipation}

Topel (1986) explores the idea that labor markets adjust in anticipation (concurrently or even before a demand or supply shift actually occurs). It is difficult to judge how sophisticated expectations are or how strongly households and firms may respond to them. Immigrant arrival rates across cities in the U.S. have been so stable and predictable that some degree of anticipation seems likely. Eberts and Stone (1992) argue, however, that the assumption of households moving years in advance of an anticipated demand shocks (as in Topel 1986) is not realistic and firms and workers may not even respond at all.

We consider two cases here that, together with our baseline case in which anticipation plays no role, may perhaps bound the truth. In the first version, the expected inflow of migrants equals the current rate, i.e. $E\left[m_{j t+1}\right]=m_{j t}$. In the second version, agents combine the observed composition of immigrants in their city with a correct forecast of the national inflow in the next period, i.e. $E\left[m_{j t+1}\right] \cong \widetilde{m}_{j t+1}$. In the first model agents are naïve, simply extrapolating from the current to the next period. In the second they predict as well as an econometrician armed with (ex post) Census data.

If the capital-to-labor ratio responds similarly to anticipated and realized shocks, then the error correction model changes from equation (8) to

$$
\log k_{j t}=\log k_{j t-1}-m_{j t}+\gamma\left(\log k_{j t-1}^{*}-\log k_{j t-1}+E\left[m_{j t}\right]\right) .
$$

With "naïve" expectations, $E\left[m_{j t+1}\right]=m_{j t}$, equation (14) would, for example, change to

$$
\operatorname{plim} \tilde{\beta}_{1 \mid t=2}^{I V}=\beta_{1}+\ldots-2 \gamma \beta_{1} \frac{\operatorname{Cov}\left(\tilde{m}_{j 2}, m_{j 1}\right)}{\operatorname{Cov}\left(\tilde{m}_{j 2}, m_{j 2}\right)}
$$

where for simplicity we have ignored the terms involving demand shocks. The bias from a response to the supply shock is now twice as large, because the capital-labor ratio responds both to the immigrant inflow in $t=1$ as well as to the expected inflow in $t=2$, and the latter is equal to the former. With the "sophisticated" expectation $E\left[m_{j t+1}\right]=\widetilde{m}_{j t+1}$, the estimates in $t=1$ would also be affected, and equation (14) would instead change to 


$$
\operatorname{plim} \tilde{\beta}_{1 \mid t=2}^{I V}=\beta_{1}+\ldots-\gamma \beta_{1} \frac{\operatorname{Cov}\left(\tilde{m}_{j 2}, m_{j 1}\right)}{\operatorname{Cov}\left(\tilde{m}_{j 2}, m_{j 2}\right)}-\gamma \beta_{1}
$$

The bias is similar in both anticipation models if $\operatorname{Cov}\left(\tilde{m}_{j 2}, m_{j 1}\right) \approx \operatorname{Cov}\left(\tilde{m}_{j 2}, m_{j 2}\right)$. Extending these arguments to a generic period $t$ shows that under either anticipation model, the bias term is largest in the period after a structural break in the distribution of immigrants occurs - in our setting, the 1980s - as the response to the unexpected immigrant inflow in the previous period coincides with the response to updated beliefs about their distribution in the future. 


\section{Figure 1}

Interdecadal Correlation of Composition of Immigrant Arrivals to the U.S.
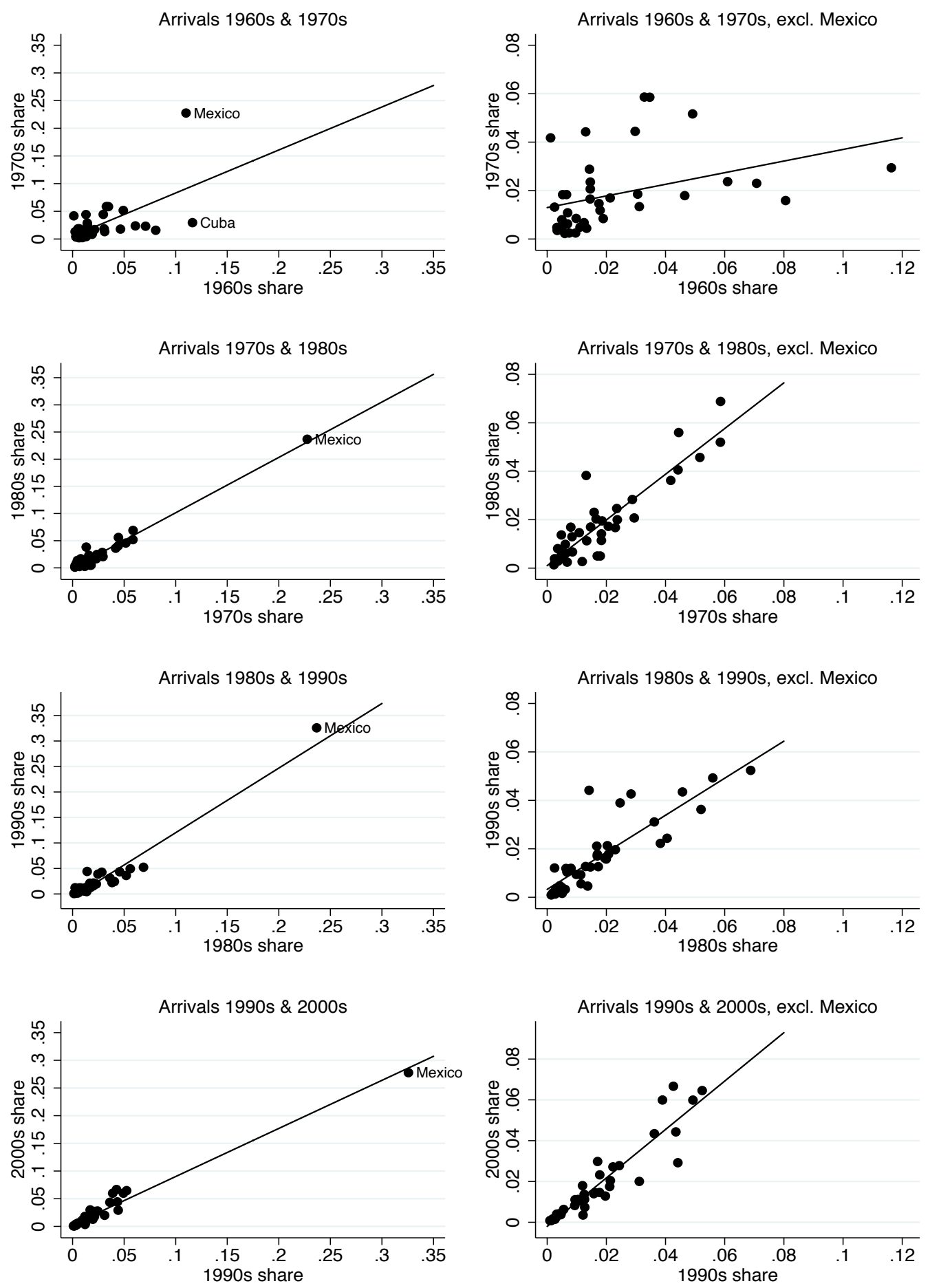

Note: Authors' calculations using U.S. Census (1970-2000) and ACS (2007-2011) data from 39 countries of origin. Each observation is the share of all newly-arrived immigrants that were born in a specific country. 
Table 1

Characteristics of Immigrant Inflows

\begin{tabular}{|c|c|c|c|c|c|c|c|}
\hline Census Year: & 1950 & 1960 & 1970 & 1980 & 1990 & 2000 & 2010 \\
\hline \multicolumn{8}{|l|}{ Panel A: Share of Recent Arrivals } \\
\hline Nation & & & 0.016 & 0.025 & 0.037 & 0.044 & 0.032 \\
\hline Average MSA & & & 0.014 & 0.020 & 0.029 & 0.037 & 0.028 \\
\hline Standard deviation across MSAs & & & 0.018 & 0.022 & 0.034 & 0.030 & 0.019 \\
\hline \multicolumn{8}{|l|}{ Panel B: Share of Recent Arrivals From } \\
\hline Canada and Europe & & & 0.414 & 0.173 & 0.131 & 0.164 & 0.117 \\
\hline Mexico & & & 0.110 & 0.228 & 0.237 & 0.326 & 0.278 \\
\hline Other Latin America & & & 0.258 & 0.196 & 0.236 & 0.207 & 0.234 \\
\hline Asia & & & 0.168 & 0.319 & 0.319 & 0.261 & 0.307 \\
\hline Recent arrivals, excluding Mexico & & & & 0.37 & 0.95 & 0.90 & 0.95 \\
\hline Immigrant stocks, 16 origins (excl. Other) & 0.99 & 0.99 & 0.94 & 0.65 & 0.90 & 0.97 & $>0.99$ \\
\hline
\end{tabular}

Note: Authors' calculations using U.S. Census (1970-2000) and ACS (2007-2011) data from 109 MSAs. The column headings refer to the Census year from which the data were taken. Recent arrivals are immigrants who arrived in the decade prior to the Census year. 
Table 2

Estimated Impact of Immigration on Natives' Wages

\begin{tabular}{lccccc}
\hline Census Year: & $\mathbf{1 9 7 0}$ & $\mathbf{1 9 8 0}$ & $\mathbf{1 9 9 0}$ & $\mathbf{2 0 0 0}$ & $\mathbf{2 0 1 0}$ \\
\hline Panel A: OLS & & & & & \\
Immigrant Inflows & 0.120 & -0.156 & $0.452 * *$ & 0.173 & 0.027 \\
& $(0.155)$ & $(0.139)$ & $(0.140)$ & $(0.129)$ & $(0.149)$
\end{tabular}

Panel B: 2SLS (Current Instrument)

Second stage

Immigrant Inflows

$\begin{array}{llccc}0.183 & -0.342 & 0.398 * * & -0.045 & 0.017 \\ (0.211) & (0.184) & (0.114) & (0.113) & (0.144)\end{array}$

First stage

$\begin{array}{cccccc}\text { Past Settlement Instrument } & 1.121 * * & 0.686 * * & 0.976 * * & 0.629 * * & 0.749 * * \\ & (0.216) & (0.132) & (0.175) & (0.114) & (0.058)\end{array}$

$\begin{array}{llllll}\text { First stage } R^{2} & 0.819 & 0.674 & 0.775 & 0.655 & 0.832\end{array}$

Note: Authors' calculations using U.S. Census (1960-2000) and ACS (2007-2011) data from 109 MSAs. The column headings refer to the Census year from which the data were taken. The base year used in construction of the instrument is taken from the Census 10 years prior to the indicated Census year. The table reports the slope coefficient in a regression of the change in residual log wage on the immigrant inflow rate in the decade preceding each census year. Robust standard errors in parentheses. $* *$ indicates $p<0.01, *$ indicates $p<0.05$. 
Table 3

Correlations in Local Immigrant Inflows

\begin{tabular}{lcccc}
\hline Census year: & $\mathbf{1 9 8 0}$ & $\mathbf{1 9 9 0}$ & $\mathbf{2 0 0 0}$ & $\mathbf{2 0 1 0}$ \\
\hline Panel A: Serial Correlation & & & & \\
Immigrant Inflows & 0.82 & 0.96 & 0.92 & 0.96 \\
Past Settlement Instrument & 0.70 & 0.99 & 0.96 & 0.99
\end{tabular}

Panel B: Cross-Sectional Correlation of Immigrant Inflows and Instruments

Correlation of Immigrant Inflows with

$\begin{array}{lllll}\text { Instrument base period } t-1 & 0.82 & 0.88 & 0.81 & 0.91 \\ \text { Instrument base period } t-2 & 0.73 & 0.69 & 0.68 & 0.78\end{array}$

Correlation of Lagged Immigrant Inflows with:

$\begin{array}{lllll}\text { Instrument base period } t-1 & 0.62 & 0.96 & 0.93 & 0.95\end{array}$

$\begin{array}{lllll}\text { Instrument base period } t-2 & 0.51 & 0.81 & 0.81 & 0.83\end{array}$

Panel C: Serial Correlation by Skill Group

Immigrant Inflows

$\begin{array}{lllll}\text { High skilled } & 0.79 & 0.95 & 0.94 & 0.97 \\ \text { Low skilled } & 0.81 & 0.95 & 0.88 & 0.93 \\ \log \text { (High skilled/Low skilled) } & 0.62 & 0.80 & 0.76 & 0.73\end{array}$

Past Settlement Instrument

$\begin{array}{lllll}\text { High skilled } & 0.70 & 0.97 & 0.98 & 0.99 \\ \text { Low skilled } & 0.72 & 0.98 & 0.98 & 0.99 \\ \log \text { (High skilled/Low skilled) } & 0.88 & 0.95 & 0.99 & 0.99\end{array}$

Note: Authors' calculations using U.S. Census (1970-2000) and ACS (2007-2011) data 109 MSAs. Each entry is a pairwise correlation across 109 MSAs. Panels A (all immigrants) and $\mathrm{C}$ (subgroups and ratios) report the serial correlations in actual inflows and in the past settlement IV. Panel B shows the correlation between the IV and the inflow it is supposed to predict, with that between the IV and the previous inflow. Low skilled are workers with at most a high school degree. High skill workers are those with more than a high school degree. Base period $t-1$ and $t-2$ mean that the instrument is constructed using the immigrant distribution 10 and 20 years prior to the Census observation year, respectively. 
Table 4

Multiple Instrumentation: Reduced Form and First Stage Results

\begin{tabular}{lcccc}
\hline Census Year: & $\mathbf{1 9 8 0}$ & $\mathbf{1 9 9 0}$ & $\mathbf{2 0 0 0}$ & $\mathbf{2 0 1 0}$ \\
\hline Reduced Form: & & & & \\
Past Settlement Instrument & $-0.382 * *$ & 0.016 & -0.469 & -0.005 \\
& $(0.107)$ & $(0.446)$ & $(0.295)$ & $(0.951)$ \\
Lagged Past Settlement Instrument & $0.200 * *$ & 0.263 & 0.469 & 0.052 \\
& $(0.073)$ & $(0.448)$ & $(0.345)$ & $(0.943)$
\end{tabular}

First Stages:

Kleibergen-Paap rk LM statistic

$\begin{array}{rrrr}6.720 & 2.170 & 0.960 & 0.072 \\ {[0.010]} & {[0.141]} & {[0.326]} & {[0.397]}\end{array}$

Immigrant Inflows

Past Settlement Instrument

$0.186 * \quad-0.283$

$-0.781$

1.142

Lagged Past Settlement Instrument

(0.090)

(0.452)

(0.431)

(0.584)

$0.501 * *$

0.984

$1.429 * *$

$-0.599$

(0.117)

(0.535)

(0.463)

(0.581)

F

216.9

5.6

26.3

21.4

Lagged immigrant inflows

Past Settlement Instrument

$-0.313 * *$

0.047

$-0.913$

1.578

Lagged Past Settlement Instrument

(0.066)

(0.229)

$(0.505)$

$(0.868)$

$0.947 * *$

0.426

$1.898 * *$

$-0.704$

(0.091)

(0.255)

(0.523)

(0.866)

F

139.7

13.6

39.7

28.6

Note: Authors' calculations using U.S. Census (1960-2000) and ACS (2007-2011) data from 109 MSAs. The dependent variable is the change in residual log wages by MSA. The column headings refer to the Census year from which the data were taken. Both instruments are created using countryof-origin immigrant shares from 20 years prior to the Census year. The reduced form reports the slope coefficients from an OLS regression of the change in residual log wage on both instruments. First stage results are from regressions of the immigrant inflow rate and lagged immigrant inflow rate on both instruments. Robust standard errors in parentheses. $p$-values in square brackets. ** indicates $\mathrm{p}<0.01, *$ indicates $\mathrm{p}<0.05$. 
Table 5

Multiple Instrumentation: Estimated Impact of Immigration on Natives' Wages , 1970s

\begin{tabular}{|c|c|c|c|c|c|c|}
\hline Notes: & (1) & $\begin{array}{c}\text { (2) } \\
\text { Trim Bottom } \\
5 \% \text { of Wages } \\
\end{array}$ & $\begin{array}{c}\text { (3) } \\
\text { Weight: } \\
\text { Population }\end{array}$ & $\begin{array}{c}\text { (4) } \\
\text { Weight: } \\
\log (\text { Population })\end{array}$ & $\begin{array}{c}\text { (5) } \\
\text { Bartik } \\
\text { Control Var. }\end{array}$ & $\begin{array}{c}\text { (6) } \\
\text { Division } \\
\text { Fixed Effects } \\
\end{array}$ \\
\hline \multicolumn{7}{|l|}{ Panel A: 2SLS (Current Instrument) } \\
\hline Immigrant Inflows & $\begin{array}{l}-0.430 * \\
(0.199)\end{array}$ & $\begin{array}{l}-0.440 * \\
(0.180)\end{array}$ & $\begin{array}{l}-0.193 \\
(0.117)\end{array}$ & $\begin{array}{l}-0.407 * \\
(0.195)\end{array}$ & $\begin{array}{l}-0.454 * \\
(0.205)\end{array}$ & $\begin{array}{l}-0.684 * \\
(0.279)\end{array}$ \\
\hline \multicolumn{7}{|c|}{ Panel B: 2SLS (Current and Lagged Instruments) } \\
\hline Immigrant Inflows & $\begin{array}{l}-0.898 * * \\
(0.314)\end{array}$ & $\begin{array}{l}-0.850 * * \\
(0.271)\end{array}$ & $\begin{array}{l}-0.406 \\
(0.263)\end{array}$ & $\begin{array}{l}-0.869 * * \\
(0.315)\end{array}$ & $\begin{array}{l}-0.941 * * \\
(0.330)\end{array}$ & $\begin{array}{l}-1.591 * * \\
(0.518)\end{array}$ \\
\hline Lagged Immigrant Inflows & $\begin{array}{l}0.687 * * \\
(0.239)\end{array}$ & $\begin{array}{l}0.602 * * \\
(0.199)\end{array}$ & $\begin{array}{c}0.308 \\
(0.232)\end{array}$ & $\begin{array}{l}0.669 * * \\
(0.240)\end{array}$ & $\begin{array}{l}0.714 * * \\
(0.260)\end{array}$ & $\begin{array}{l}1.123 * * \\
(0.356)\end{array}$ \\
\hline \multicolumn{7}{|c|}{ Panel C: Reduced Form (Current and Lagged Instruments } \\
\hline Past Settlement Instrument & $\begin{array}{l}-0.382 * * \\
(0.107)\end{array}$ & $\begin{array}{l}-0.346 * * \\
(0.093)\end{array}$ & $\begin{array}{l}-0.316 * \\
(0.128)\end{array}$ & $\begin{array}{l}-0.381 * * \\
(0.108)\end{array}$ & $\begin{array}{l}-0.400 * * \\
(0.116)\end{array}$ & $\begin{array}{l}-0.517 * * \\
(0.187)\end{array}$ \\
\hline Lagged Past Settlement Instrument & $\begin{array}{l}0.323 * * \\
(0.117)\end{array}$ & $\begin{array}{l}0.320 * * \\
(0.105)\end{array}$ & $\begin{array}{c}0.233 \\
(0.157)\end{array}$ & $\begin{array}{l}0.325 * * \\
(0.116)\end{array}$ & $\begin{array}{l}0.331 * \\
(0.128)\end{array}$ & $\begin{array}{l}0.385 * * \\
(0.176)\end{array}$ \\
\hline
\end{tabular}

Note: Authors' calculations using 1960-1980 U.S. Census data from 109 MSAs. The dependent variable is the change in residual log wages by MSA between the 1970 and 1980 Census. Both instruments are created using country-of-origin immigrant shares from 1960. In column (2), the bottom bottom $5 \%$ of wages are trimmed. In column (3) observations are weighted by lagged total population in the MSA. In column (4) observations are weighted by the lagged log population. In column (5) observations include a "Bartik" variable to control for changes in industry composition (see text). Column (6) includes Census division fixed effects. Robust standard errors in parentheses. ** indicates $p<0.01, *$ indicates $p<0.05$. 


\section{Table 6}

Multiple Instrumentaiton:

Estimated Impact of Immigration on Natives' Wages for Subgroups, 1970s

\begin{tabular}{llllll}
\hline \multirow{2}{*}{ Subgroup } & \multicolumn{2}{c}{ Imm. Inflows } & & \multicolumn{2}{c}{ Lagged Imm. Inflows } \\
\cline { 2 - 3 } \cline { 6 - 7 } & Coeff. & Std. Err. & & Coeff. & Std. Err. \\
All & $-0.898 * *$ & 0.314 & & $0.687 * *$ & 0.239 \\
Male & -0.754 & 0.394 & & 0.516 & 0.297 \\
Education & & & & & \\
$\quad$ High School or Less & $-0.980 * *$ & 0.350 & & $0.705 * *$ & 0.268 \\
$\quad$ More than High School & -0.618 & 0.422 & & 0.615 & 0.431 \\
Age & & & & & \\
$\quad$ 30 or Younger & $-1.146 * *$ & 0.436 & & $1.026 * *$ & 0.325 \\
$\quad$ 31-50 & $-0.615 *$ & 0.278 & & 0.412 & 0.213 \\
$\quad$ 51-64 & -0.743 & 0.644 & & 0.532 & 0.462 \\
30 or Younger and Low Skilled & $-1.313 *$ & 0.561 & & $1.042 *$ & 0.412 \\
\hline
\end{tabular}

Note: Authors' calculations using 1960-1980 U.S. Census data from 109 MSAs. The dependent variable is the change in residual log wages by MSA between the 1970 and 1980 Census. Both instruments are created using country-of-origin immigrant shares from 1960. Low skilled are workers with at most a high school degree. High skill workers are those with more than a high school degree. Estimation by 2SLS. Base period is 1960 for both instruments. Robust standard errors in parentheses. ${ }^{*}$ indicates $\mathrm{p}<0.01,{ }^{*}$ indicates $\mathrm{p}<0.05$. 
Table A.1

Selected Publications using the Past Settlement Instrument

\begin{tabular}{|c|c|c|c|}
\hline Authors & Year & Journal & Outcome \\
\hline Card and DiNardo & 2000 & AER: Pap. \& Proc. & Internal migration \\
\hline Fairlie and Meyer & 2003 & J. Labor Econ. & Native self-employment \\
\hline Dustmann, Fabbri, and Preston & 2005 & Economic J. & Native labor market outcomes \\
\hline Ottaviano and Peri & 2006 & J. Econ. Geog. & Native wages and housing market \\
\hline Reed and Danziger & 2007 & AER: Pap. \& Proc. & Native labor market outcomes \\
\hline Saiz & 2007 & J. Urban Econ. & Housing market \\
\hline Cortés & 2008 & J. Political Econ. & Prices (goods and services) \\
\hline Peri and Sparber & 2009 & AEJ: Applied Econ. & Task specialization \\
\hline Boustan & 2010 & Quarterly J. Econ. & Residential segregation \\
\hline Furtado and Hock & 2010 & AER: Pap. \& Proc. & Fertility \\
\hline Hunt and Gauthier-Loiselle & 2010 & AEJ: Macro & Innovation \\
\hline Kerr and Lincoln & 2010 & J. Labor Econ. & Science and engineering, patenting \\
\hline Cortés and Tessada & 2011 & AEJ: Applied Econ. & Labor supply, household work and services \\
\hline Farré, Gonzéalez, and, Ortega & 2011 & B.E.J. Econ. $A \& P$ & Female labor supply \\
\hline González and Ortega & 2011 & Labour Econ. & Labor market outcomes \\
\hline Lewis & 2011 & Quarterly J. Econ. & Investment in automation \\
\hline Smith & 2012 & J. Labor Econ. & Youth employment \\
\hline Wozniak and Murray & 2012 & J. Urban Econ. & Population, internal migration \\
\hline
\end{tabular}


Table A.1, continued

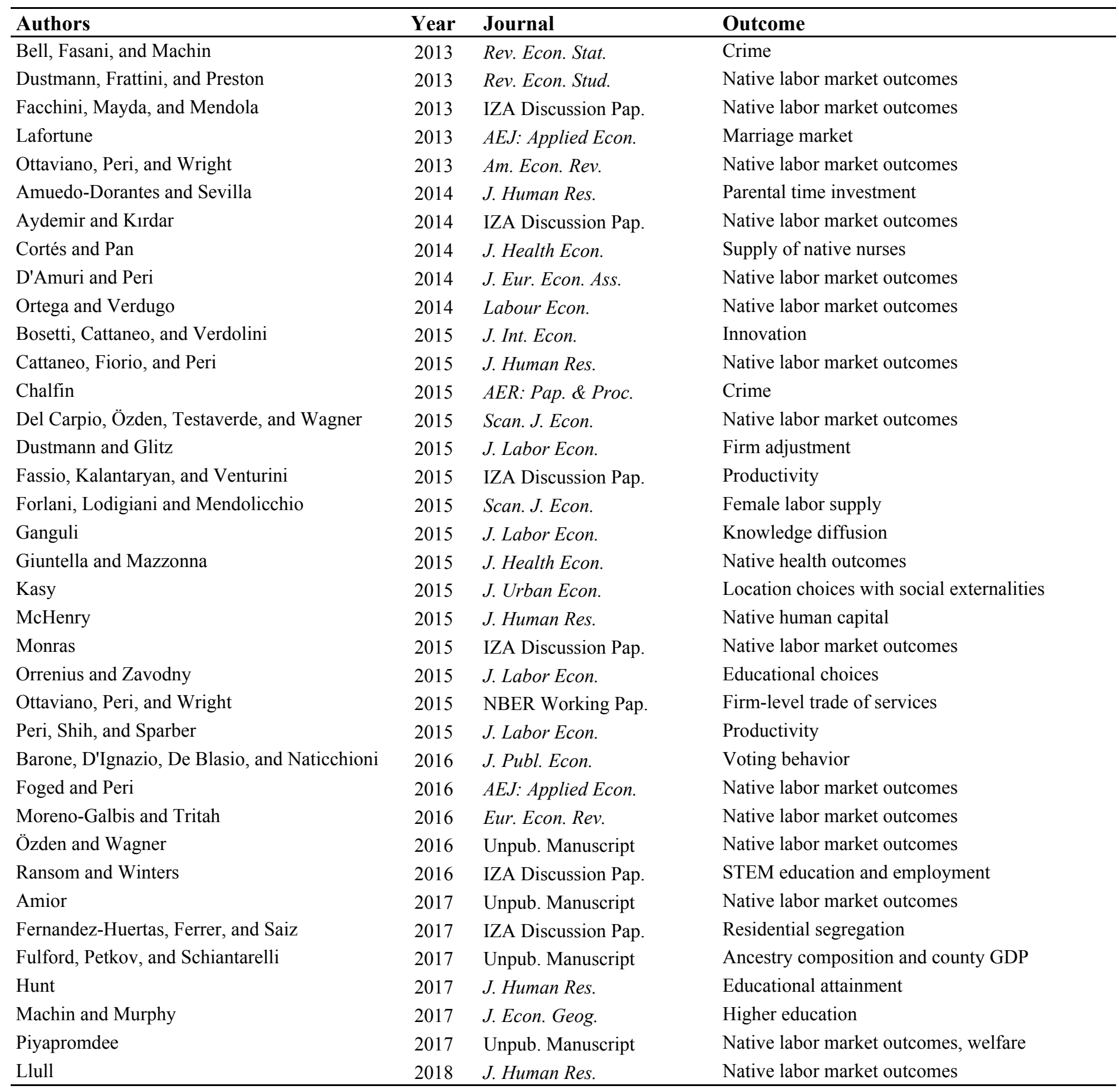


Appendix Table B.1

Estimated Impact of Immigration on Natives' Wages, Commuting Zones

\begin{tabular}{lllll}
\hline Census Year: & $\mathbf{1 9 8 0}$ & $\mathbf{1 9 9 0}$ & $\mathbf{2 0 0 0}$ & $\mathbf{2 0 1 0}$ \\
\hline Panel A: OLS & & & & \\
Immigrant Inflows & $-0.210^{* *}$ & $0.605 * *$ & -0.014 & 0.060 \\
& $(0.077)$ & $(0.094)$ & $(0.107)$ & $(0.115)$
\end{tabular}

Panel B: 2SLS (Current Instrument)

Second stage

Immigrant Inflows

$\begin{array}{llll}-0.315 * * & 0.595 * * & -0.222 & 0.060\end{array}$

$\begin{array}{llll}(0.095) & (0.089) \quad(0.170) & (0.091)\end{array}$

First stage

Past Settlement Instrument

$\begin{array}{llll}0.782 * * & 1.017 * * & 0.602 * * & 0.678 * * \\ (0.166) & (0.057) & (0.115) & (0.082)\end{array}$

First stage $R^{2}$

$0.663 \quad 0.891$

0.714

0.823

Note: Authors' calculations using U.S. Census (1960-2000) and ACS (2007-2011) data from 741 commuting zones. The column headings refer to the Census year from which the data were taken. The base year used in construction of the instrument is taken from the Census 10 years prior to the indicated Census year. The table reports the slope coefficient in a regression of the change in residual log wage on the immigrant inflow rate in the decade preceding each census year. Robust standard errors in parentheses. ** indicates $p<0.01$, * indicates $p<0.05$. 


\section{Appendix Table B.2}

Multiple Instrumentation:

Estimated Impact of Immigration on Natives' Wages for Commuting Zones, 1970s

(1) (2) (5)

Notes:

\begin{tabular}{ccc} 
Trim Bottom & Bartik & Division \\
$5 \%$ of Wages & Control Var. & Fixed Effects \\
\hline
\end{tabular}

Panel A: 2SLS (Current Instrument)

Immigrant Inflows

$\begin{array}{llll}-0.294 * & -0.312 * * & -0.318 * & -0.520 * * \\ (0.199) & (0.118) & (0.140) & (0.192)\end{array}$

Panel B: 2SLS (Current and Lagged Instruments)

$\begin{array}{llllc}\text { Immigrant Inflows } & -0.416 & -0.388 * & -0.447 & -0.889 * \\ & (0.219) & (0.178) & (0.240) & (0.371) \\ \text { Lagged Immigrant Inflows } & 0.197 & 0.123 & 0.208 & 0.471 \\ & (0.164) & (0.123) & (0.194) & (0.267)\end{array}$

Panel C: Reduced Form (Current and Lagged Instruments)

\begin{tabular}{llllc} 
Past Settlement Instrument & $-0.196 * *$ & $-0.183 * *$ & $-0.212 * *$ & $-0.291 * *$ \\
& $(0.059)$ & $(0.054)$ & $(0.061)$ & $(0.070)$ \\
Lagged Past Settlement Instrument & 0.038 & 0.027 & 0.038 & 0.065 \\
& $(0.067)$ & $(0.085)$ & $(0.064)$ & $(0.094)$ \\
\hline
\end{tabular}

Note: Authors' calculations using 1970-1980 U.S. Census data from 741 Commuting Zones. The dependent variable is the change in residual log wages by MSA between the 1970 and 1980 Census. Both instruments are created using country-of-origin immigrant shares from 1960. In column (2), the bottom bottom 5\% of wages are trimmed. In column (5) observations include a "Bartik" variable to control for changes in industry composition (see text). Column (6) includes Census division fixed effects. Robust standard errors in parentheses. ** indicates $p<0.01, *$ indicates $p<0.05$. 